\title{
Interneuron Origins in the Embryonic Porcine Medial Ganglionic Eminence
}

\author{
${ }^{\circledR}$ Mariana L. Casalia, ${ }^{1}$ Tina Li, ${ }^{1}{ }^{\circledR}$ Harrison Ramsay, ${ }^{1}$ Pablo J. Ross, ${ }^{2}$ Mercedes F. Paredes, ${ }^{3,4}$ and \\ (1) Scott C. Baraban ${ }^{3,4,5}$ \\ ${ }^{1}$ Department of Neurological Surgery, University of California San Francisco, San Francisco, California 94143, ${ }^{2}$ Department of Animal Science, \\ University of California Davis, Davis, California 94143, ${ }^{3}$ Department of Neurology, University of California San Francisco, San Francisco, California \\ 94143, ${ }^{4}$ Weill Institute for Neurosciences, University of California San Francisco, San Francisco, California 94143, and ${ }^{5}$ Helen Wills Institute for \\ Neuroscience, University of California Berkeley, Berkeley, California 94720
}

Interneurons contribute to the complexity of neural circuits and maintenance of normal brain function. Rodent interneurons originate in embryonic ganglionic eminences, but developmental origins in other species are less understood. Here, we show that transcription factor expression patterns in porcine embryonic subpallium are similar to rodents, delineating a distinct medial ganglionic eminence (MGE) progenitor domain. On the basis of Nkx2.1, Lhx6, and Dlx2 expression, in vitro differentiation into neurons expressing GABA, and robust migratory capacity in explant assays, we propose that cortical and hippocampal interneurons originate from a porcine MGE region. Following xenotransplantation into adult male and female rat hippocampus, we further demonstrate that porcine MGE progenitors, like those from rodents, migrate and differentiate into morphologically distinct interneurons expressing GABA. Our findings reveal that basic rules for interneuron development are conserved across species, and that porcine embryonic MGE progenitors could serve as a valuable source for interneuron-based xenotransplantation therapies.

Key words: GABA; development; hippocampus; interneuron; porcine

Significance Statement

Here we demonstrate that porcine medial ganglionic eminence, like rodents, exhibit a distinct transcriptional and interneuron-specific antibody profile, in vitro migratory capacity and are amenable to xenotransplantation. This is the first comprehensive examination of embryonic interneuron origins in the pig; and because a rich neurodevelopmental literature on embryonic mouse medial ganglionic eminence exists (with some additional characterizations in other species, e.g., monkey and human), our work allows direct neurodevelopmental comparisons with this literature.

\section{Introduction}

Excitatory glutamatergic neurons and inhibitory GABAergic interneurons represent the two primary neuronal populations in mammalian brain. Cortical and hippocampal inhibitory interneurons are a diverse subset of the total neuronal population, mediate many critical brain functions, and arise from embryonic

Received Oct. 27, 2020; revised Dec. 18, 2020; accepted Jan. 8, 2021.

Author contributions: M.L.C., M.F.P., and S.C.B. designed research; M.L.C., T.L., H.R., and M.F.P. performed research; M.L.C., T.L., H.R., M.F.P., and S.C.B. analyzed data; M.L.C. wrote the first draft of the paper; M.L.C., M.F.P., and S.C.B. edited the paper; P.J.R. contributed unpublished reagents/analytic tools; S.C.B. wrote the paper.

The authors declare no competing financial interests.

This work was supported by National Institutes of Health, National Institute of Neurological Disorders and Stroke R37 Award NS071785, and UCSF Program for Breakthrough Biomedical Research Award to S.C.B. This work was also supported by the National Swine Resource Center by supplying pig embryos for our research under Grant U42-0D011140. We thank Rosalia Paterno, Colleen Carpenter, and Joseane Righes Marafiga for technical support and advice.

Correspondence should be addressed to Scott C. Baraban at scott.baraban@ucsf.edu.

https://doi.org/10.1523/JNEUROSCI.2738-20.2021

Copyright $\odot 2021$ the authors subpallium regions (Fishell, 2007; Gelman et al., 2012; Kessaris et al., 2014). A wide spectrum of neurologic pathologies is associated with loss, or dysfunction, of interneurons, including, butnot limited to, epilepsy, autism spectrum disorder, Alzheimer's disease, and schizophrenia (Marin, 2012; Inan et al., 2013; Paterno et al., 2020). Studies over the past decade demonstrated that transplantation of interneurons offers great promise for treatment of these disorders (Alvarez-Buylla et al., 2000; Baraban et al., 2009; Anderson and Baraban, 2012; Bráz et al., 2012; Hunt et al., 2013; Tong et al., 2014; Donegan et al., 2017; Juarez-Salinas et al., 2019; Zhu et al., 2019). Interneuron transplantation studies are largely based on harvesting progenitor cells from a medial ganglionic eminence (MGE) subregion. MGE progenitors give rise to cortical GABAergic interneurons subtypes expressing parvalbumin (PV) and somatostatin (SOM) (Gelman et al., 2012; Hu et al., 2017; Pelkey et al., 2017), along with hippocampal neurogliaform and Ivy cells expressing nitric oxide synthase (Tricoire et al., 2010). These interneurons exhibit highly migratory capabilities and unique functions. To date, the majority of successful 
Table 1. Porcine MGE donor cell manipulations

\begin{tabular}{lllll}
\hline & \multicolumn{2}{l}{ Post hoc histology } & & Total $(n)$ \\
\cline { 2 - 5 } Donor cells $^{\mathrm{a}}$ & With cells & No cells & 25 & Transplant survival rate (\%) \\
\hline pMGE wt + lenti CMV GFP/ immunosuppression & 10 & 15 & 20 & 40 \\
pMGE wt + lenti CMV GFP/NO immunosuppression & 1 & 19 & 50 & 5 \\
pMGE GFP/ immunosuppression & 19 & 31 & 38 \\
\hline
\end{tabular}

${ }^{a}$ Immunosuppression cocktail: methylprednisolone acetate $(2 \mathrm{mg} / \mathrm{kg})$, cyclosporine $(20 \mathrm{mg} / \mathrm{kg})$, and azathioprine $(5 \mathrm{mg} / \mathrm{kg})$.

Table 2. Antibodies

\begin{tabular}{|c|c|c|c|c|}
\hline Primary antibodies & Host species & Company & Catalog \# & Dilution \\
\hline CoupTFII & Mouse & Perseus Proteomics & PP-H7147-00 & $1 / 100$ \\
\hline DBX1 & Rabbit & Abcam & ab156283 & $1 / 500$ \\
\hline$D C X$ & Mouse & Santa Cruz Biotechnology & sc- 271390 & $1 / 100$ \\
\hline Dlx2 & Mouse & Santa Cruz Biotechnology & sc-393879 & $1 / 500$ \\
\hline GABA & Rabbit & Sigma Millipore & a2052 & $1 / 500$ \\
\hline GFAP & Mouse & EnCore & MCA-5C10 & $1 / 1000$ \\
\hline GFAP & Rabbit & Dako & $Z 0334$ & $1 / 500$ \\
\hline KI67 & Mouse & BD Pharmingen & 556003 & $1 / 500$ \\
\hline KI67 & Rabbit & Proteintech & 27309-1-AP & $1 / 1000$ \\
\hline LHX6 & Rabbit & Santa Cruz Biotechnology & sc-98607 & $1 / 100$ \\
\hline LHX6 & Mouse & Santa Cruz Biotechnology & sc-271433 & $1 / 500$ \\
\hline MAP2 & Mouse & EnCore & MCA-4 h5 & $1 / 1000$ \\
\hline Nkx2.1 (TTF1) & Mouse & Progen & 16108 & $1 / 20$ \\
\hline Olig2 & Rabbit & EMD Millipore & AB9610 & $1 / 500$ \\
\hline Pax6 & Mouse & Abcam & ab78545 & $1 / 500$ \\
\hline PSA-NCAM (IgM isotype) & Mouse & Millipore & MAB5324 & $1 / 500$ \\
\hline PV & Rabbit & Swant & PV27 & NA \\
\hline PV & Rabbit & Abcam & ab11427 & NA \\
\hline PV & Chicken & EnCore & CPCA-Pvalb & NA \\
\hline SOM & Mouse & Santa Cruz Biotechnology & sc55565 & $1 / 500$ \\
\hline SOM & Goat & Santa Cruz Biotechnology & sc-7819 & $1 / 200$ \\
\hline Synaptophysin & Mouse & Santa Cruz Biotechnology & sc17750 & $1 / 100$ \\
\hline Tau & Chicken & EnCore & CPCA-Tau & $1 / 500$ \\
\hline Tuj (BIII tubulin) & Rabbit & Covance & MRB-435P & $1 / 1000$ \\
\hline VGAT & Mouse & Santa Cruz Biotechnology & sc 393373 & $1 / 100$ \\
\hline VIP & Rabbit & Abcam & AB22736 & NA \\
\hline Nitric oxide synthase & Rabbit & Millipore & AB5380 & NA \\
\hline Calbindin & Rabbit & Chemicon & AB1778 & NA \\
\hline Calretinin & Mouse & Chemicon & MAB1568 & NA \\
\hline Calretinin & Rabbit & Millipore & AB5054 & NA \\
\hline Calretinin & Mouse & Swant & 7697 & NA \\
\hline Reelin & Mouse & Millipore & MAB5364 & NA \\
\hline Reelin & Mouse & Calbiochem & 553730 & NA \\
\hline Neuropeptide Y & Rabbit & Abcam & ab30914 & NA \\
\hline \multicolumn{5}{|l|}{ Amplification system for E35 stains } \\
\hline TSA biotin system & & PerkinElmer & NEL700A001KT & \\
\hline
\end{tabular}

MGE progenitor cell transplantations showing efficacy in preclinical animal models harvest fresh murine embryonic tissue. Human "MGE-like" embryonic or induced pluripotent stem cell-derived interneurons could offer an alternative; however, these neurons fail to (1) migrate extensively or (2) differentiate to cortical or hippocampal interneuron subtypes seen with embryonic MGE progenitors, and (3) exhibit protracted functional maturation (Liu et al., 2013; Maroof et al., 2013; Nicholas et al., 2013). Human stem cells also present a risk of tumorigenesis (Carpentino et al., 2008). Although embryonic allografted fetal human tissue in Parkinson's disease patients ameliorated some symptoms of this disease in the $1990 \mathrm{~s}$ (Björklund et al., 2003), practical and ethical problems using aborted human fetal tissue have since led to an extended exploration for an alternative source(s) of suitable fetal material for transplantation (Wichterle et al., 1999).
Most successfully applied to organs, xenotransplantation from pig-to-nonhuman primate (or even pig-to-human) raises the exciting possibility that embryonic porcine tissue, perhaps coupled with techniques to genetically modify a donor pig using transgenic or CRISPR/Cas9 technologies (Cowan et al., 2019; Hryhorowicz et al., 2020), could be a viable source of transplantable interneurons. These efforts are supported by data showing similarities at the gene and protein level between humans and pigs (Sjöstedt et al., 2020). It is well established that murine MGE can be defined by transient anatomic landmarks and expression of a unique set of transcription factors (e.g., Nkx2.1, Dlx2, and Lhx6) (Corbin et al., 2003; Flames et al., 2007; Du et al., 2008; Gelman et al., 2012). Analysis in human and macaque (nonhuman Old World) monkey demonstrated a recapitulation of these murine MGE transcription factor expression patterns (Hansen et al., 2013; Ma et al., 2013). Tangential migration of interneurons 


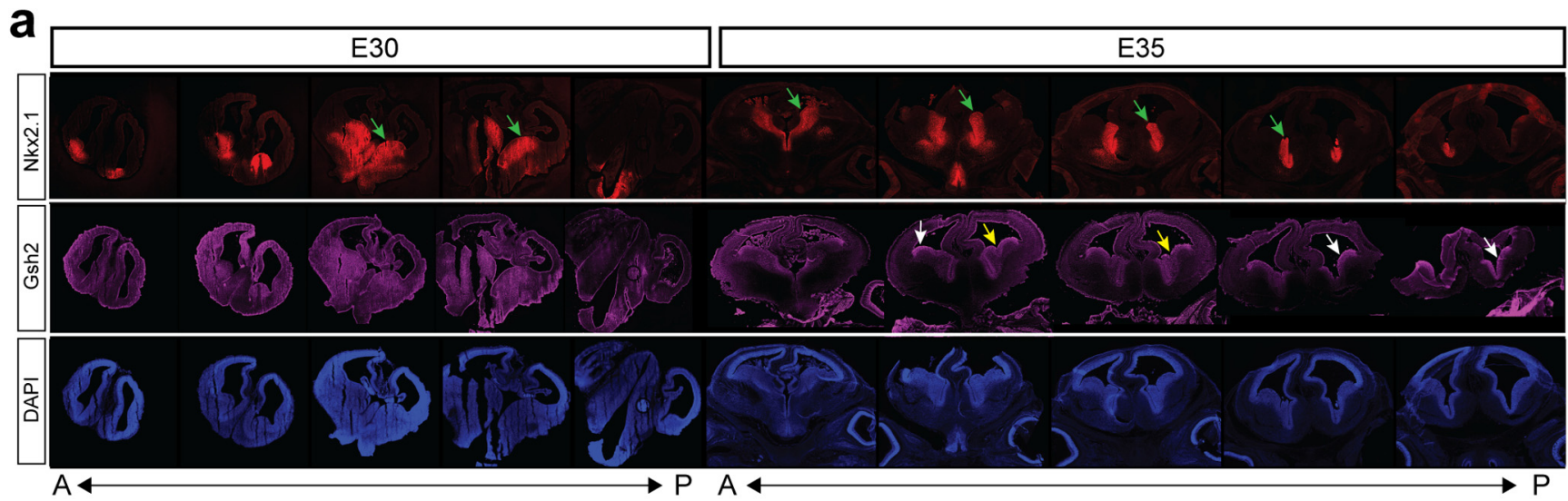

b
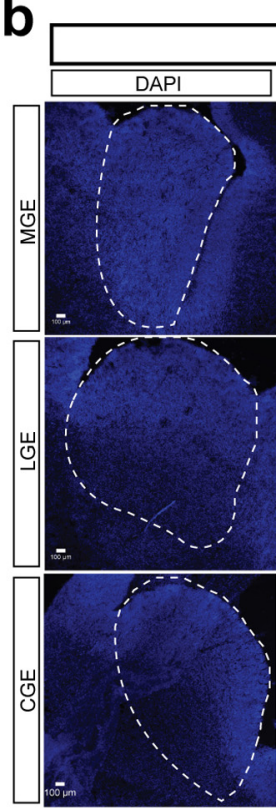
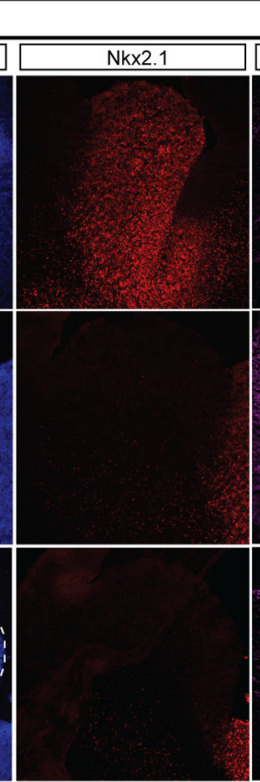
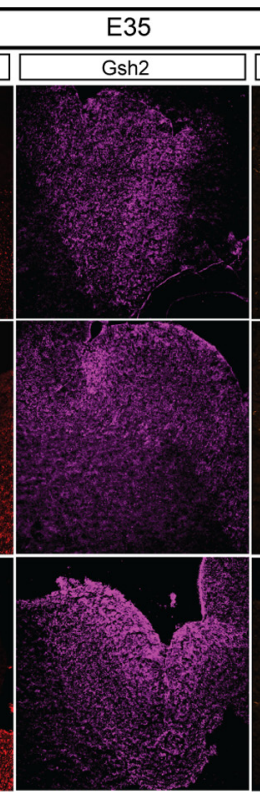
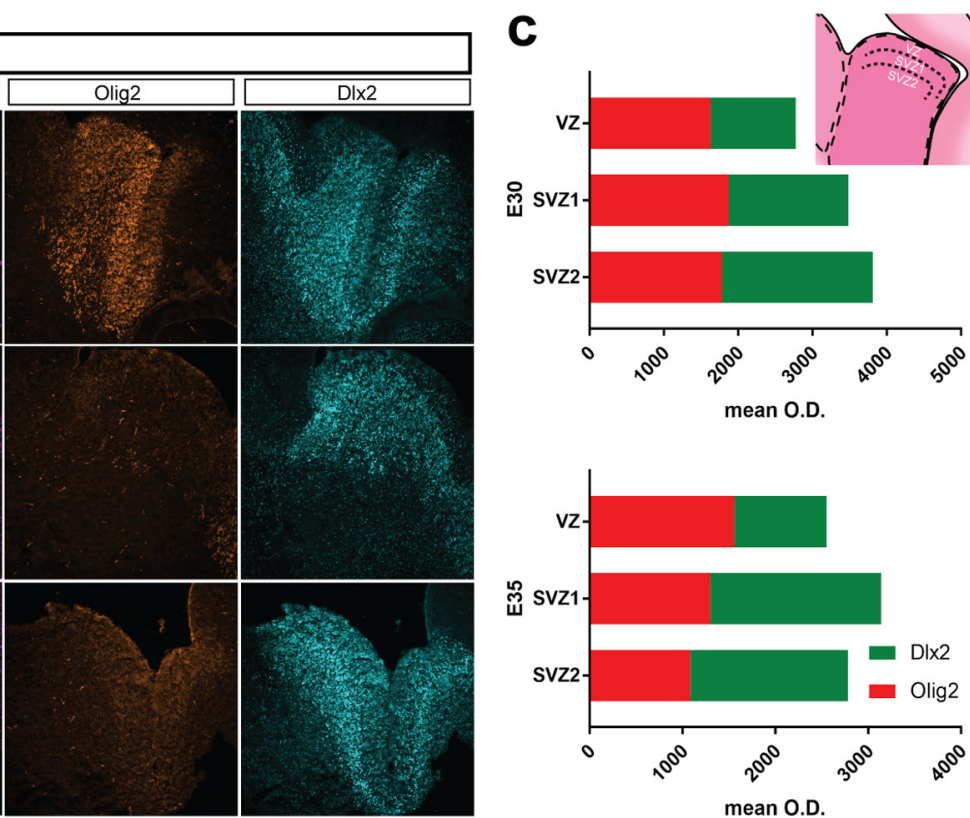

Figure 1. Developmental expansion of GEs in the pig embryonic brain. $\boldsymbol{a}$, Serial coronal sections of E30 and E35 pig brain along the anterior (A) to posterior (P) axis. Sections labeled with antibodies recognizing regional transcription factors that specify GES, Nkx2.1 (red) and Gsh2 (purple). Blue represents DAPI cell stain. Arrows indicate an anatomically defined MGE subregion; sulcus establishing a boundary between LGE and MGE became apparent at E35 (yellow arrows) and Gsh2 expression in LGE and CGE SVZ (white arrows) (E30, $n=9$; E35, $n=9$ ). $\boldsymbol{b}$, Regional (Nkx2.1, Gsh2) and temporal (0lig2, Dlx2) transcription factor expression at E35 for MGE, LGE, and CGE subregions $(n=9)$. There is distinct MGE-specific Nkx2.1 expression. Scale bar, $100 \mu \mathrm{m}$. c, Grouped summary data plots showing intermediate progenitor (DIx2) and undifferentiated radial glia (Olig2) expression at E30 and E35 ( $n=3$ ). Schematic (inset) shows where VZ, SVZ1, and SVZ2 optical density (0.D.) measurements were made.

from MGE to cortex or MGE to hippocampus is also believed to be highly conserved across species. Although some features of porcine ganglionic eminences are known, this information is limited to lateral ganglionic eminence (LGE) (Jacoby et al., 1999), a subpallial region that mainly generates olfactory bulb interneurons and lacks tangential migratory properties in vitro or following transplantation into postnatal brain.

Here we analyzed temporal and regional expression of MGE-specific transcription factors in fetal porcine brain at embryonic days 30 (E30) and 35 (E35). Cultured porcine progenitors express MGE-specific transcription factors, differentiate to $\mathrm{GABAergic} \mathrm{SOM}^{+}$interneurons, and migrate extensively in vitro. Similar to human, embryonic pig ganglionic eminence (GE) organization showed distinct organization of cells into doublecortin (DCX)-positive clusters, a pattern not seen in murine MGE. Xenotransplantation of E35 MGE progenitors into adult rat hippocampus resulted in migration across all hippocampal subfields and differentiation into
GABAergic SOM ${ }^{+}$interneurons up to $60 \mathrm{~d}$ after transplantation (DAT). Overall, patterns of transcription factor expression, differentiation into distinct interneuron subpopulations, and tangential migration capacity all appear to be conserved from rodents to pig MGE during evolution.

\section{Materials and Methods \\ Animals}

Donor porcine (Sus scrofa domesticus) embryos were procured from Department of Animal Science, University of California, Davis (English Large white) or National Swine Resource and Research Center (NSRRC:0016 GFP NT92, University of Missouri) (Whitworth et al., 2009). Adult male Sprague Dawley rats (Rattus norvegicus) were purchased from Charles River Laboratories (strain code 400) and housed under a standard $12 \mathrm{~h}$ light/dark cycle with food and water provided ad libitum. A total of 133 rats were used for xenotransplantation studies (79 female; 54 male); 75 rats received intraperitoneal injection of an immunosuppression cocktail containing methylprednisolone acetate $(2 \mathrm{mg} / \mathrm{kg})$, cyclosporine $(20 \mathrm{mg} / \mathrm{kg})$, and azathioprine $(5 \mathrm{mg} / \mathrm{kg}) 3$ times per week (Table 1). All protocols and procedures 
a
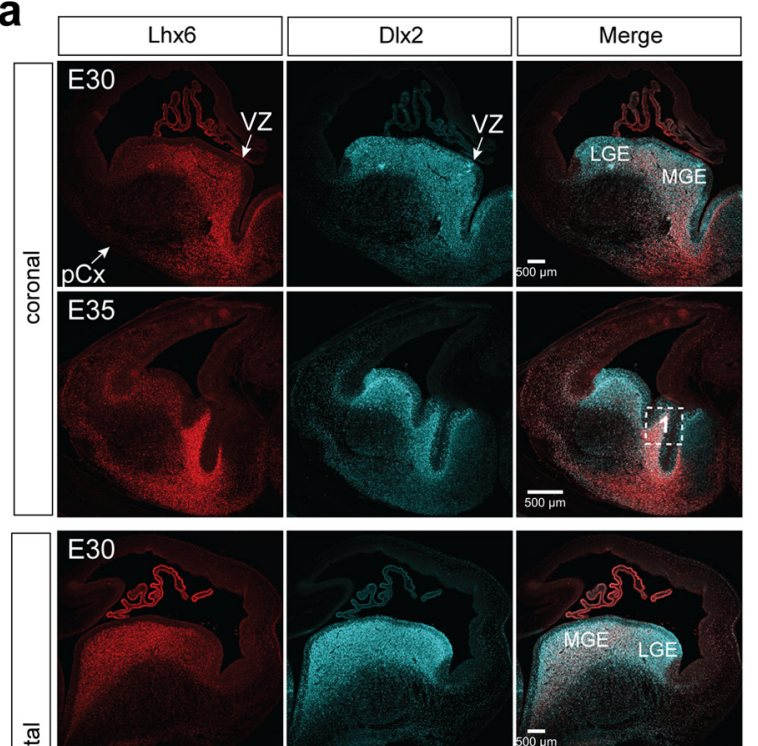

产

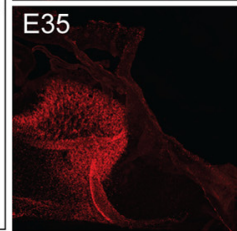

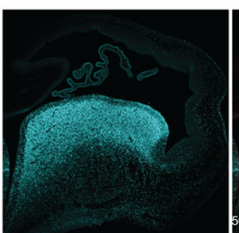
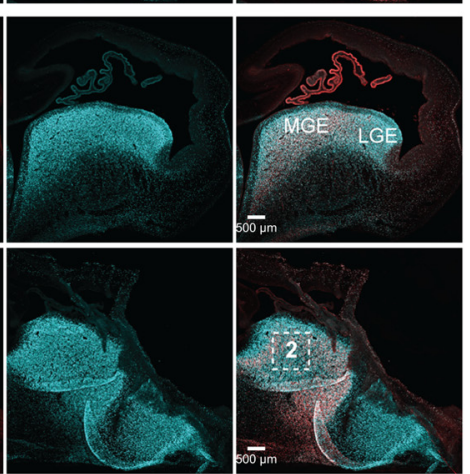

b

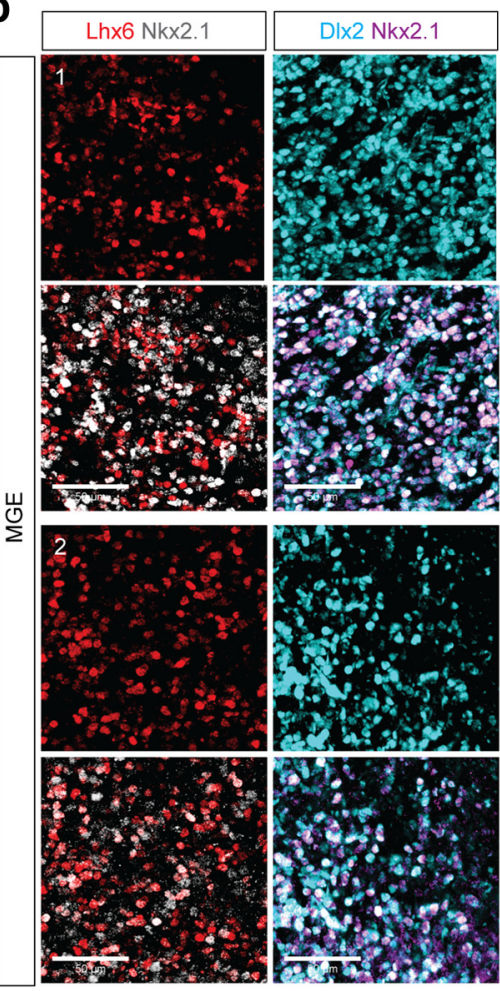

C

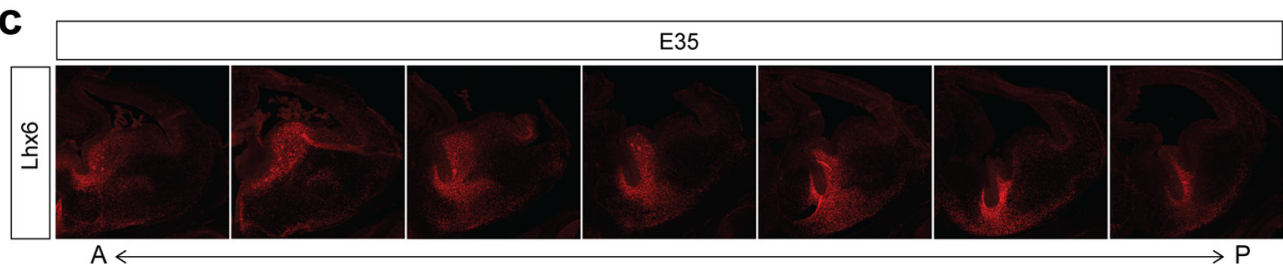

Figure 2. MGE-specific transcription factor expression in the developing porcine ventral forebrain. $\boldsymbol{a}$, Representative coronal and sagittal sections containing the medial GE region are shown at E30 and E35. Dlx2-expressing intermediate and Lhx6-expression progenitors exit the VZ to begin a tangential migration toward cortical destinations $(n=9)$. Scale bar, $500 \mu \mathrm{m}$. $\boldsymbol{b}$, Higher magnification of inset 1 and 2 of $\boldsymbol{a}$, showing MGE expression of Nkx2.1 expression. There is high coexpression of Nxk2.1 and Lhx6 (left panels) or Dlx2 (right panels), in coronal and sagittal MGE sections. Scale bar, $50 \mu \mathrm{m}$. c, Serial coronal sections of E35 brain delineating Lhx6 expression corresponding to MGE progenitor migratory routes along the anterior-to-posterior axis $(n=9)$. pCx, Piriform cortex.

were approved by the Institutional Animal Care and Use Committee (Protocol \#AN181524-02) and adhered to University of California, San Francisco Laboratory Animal Resource Center and United States Public Health policy on Humane Care and Use of Laboratory Animals guidelines.

Tissue collection and processing

Individual E30 or E35 pig embryos were maintained on ice in 50 $\mathrm{ml}$ Falcon conical centrifuge tubes (Thermo Fisher Scientific, catalog \#14-432-22) with DMEM/F12 media. Sterile techniques were used during isolation and microdissection. Cell viability on freshly dissected brain tissue was assessed using Trypan Blue (Sigma Millipore); only tissue with $\geq 90 \%$ viability was processed for cryopreservation.

\section{Immunohistochemistry}

Embryonic pig heads were removed under a stereomicroscope (Leica Microsystems, MZ12(5)) and placed individually in a $50 \mathrm{ml}$ Falcon tube containing $30 \mathrm{ml}$ of $4 \%$ PFA (w/v) in PBS at $4^{\circ} \mathrm{C}$ for $48 \mathrm{~h}$. Rats were deeply anesthetized and perfused with $300 \mathrm{ml}$ of cold $4 \%$ PFA solution. Brains were removed and postfixed overnight (ON) with 4\% PFA. Tissue was sequentially dehydrated and cryoprotected in $10 \%, 20 \%$, and $30 \%$ sucrose $(\mathrm{w} / \mathrm{v})$ in PBS at $4^{\circ} \mathrm{C}$ until sinking. Tissue was embedded in OCT compound (Tissue-Tek, \#4583) and frozen on a dry ice/ethanol slush and stored at $-80^{\circ} \mathrm{C}$ for serial sectioning on a Leica Microsystems CM1900 cryostat. Thin tissue sections ( $30 \mu \mathrm{m}$ for pig tissue; $25 \mu \mathrm{m}$ for rat tissue) were collected onto glass slides (SuperFrost Plus, catalog \#12-550-15) or free floating in cryopreservation solution (3 vol glycerol, 3 vol ethylene glycol, 4 vol $1 \times 0.1 \%$ sodium azide in PBS) and stored at $-20^{\circ} \mathrm{C}$. Tissue on SuperFrost slides was stained using TSA amplification kit (PerkinElmer; \#NEL701A001KT, \#NEL704A001KT, and \#NEL705A001KT). Briefly, cryosections were left at $\mathrm{ON}$ at room temperature (RT), baked for $15 \mathrm{~min}$ at $60^{\circ} \mathrm{C}$, and fixed for $15 \mathrm{~min}$ with $4 \%$ PFA. Antigen retrieval was performed using nearly boiling $10 \mathrm{~mm}$ sodium citrate solution (5.95$6.05 \mathrm{pH}$ range). Sections were allowed to cool down to RT, and tissue was delineated with pap-pen (Abcam, \#ab2601). Free-floating sections were left at RT for $2 \mathrm{~h}$ prior $3 \times 15 \mathrm{~min}$ washes with PBS to remove cryopreservation solution. Tissue was double stained with a primary antibody and detected with Alexa secondary antibodies (Table 2). After testing different commercially available antibodies, we failed to identify one that could reliably distinguish pig $\mathrm{PV}^{+}$, calbindin $^{+}$, calretinin ${ }^{+}$, reelin ${ }^{+}$, or $\mathrm{VIP}^{+}$interneurons. Nuclei staining was done for $5 \mathrm{~min}$ as a final step (Sigma Millipore; H33342). Briefly, sections were incubated with $0.3 \%$ Triton X-100 in PBS for $60 \mathrm{~min}$ at RT, incubated in blocking solution (10\% donkey serum, $1 \%$ BSA, $0.1 \%$ Triton-X 100 in PBS) for $60 \mathrm{~min}$, and incubated ON in primary antibody at $4^{\circ} \mathrm{C}$. The next day, sections were washed $3 \times 10 \mathrm{~min}$ in $0.05 \%$ Triton-X 100 in PBS and incubated for $120 \mathrm{~min}$ at RT in secondary antibodies. Sections were mounted onto charged slides (Thermo Fisher Scientific, Superfrost Plus) using Fluoromount-G solution (Southern Biotechnology, \#0100-01). 
a
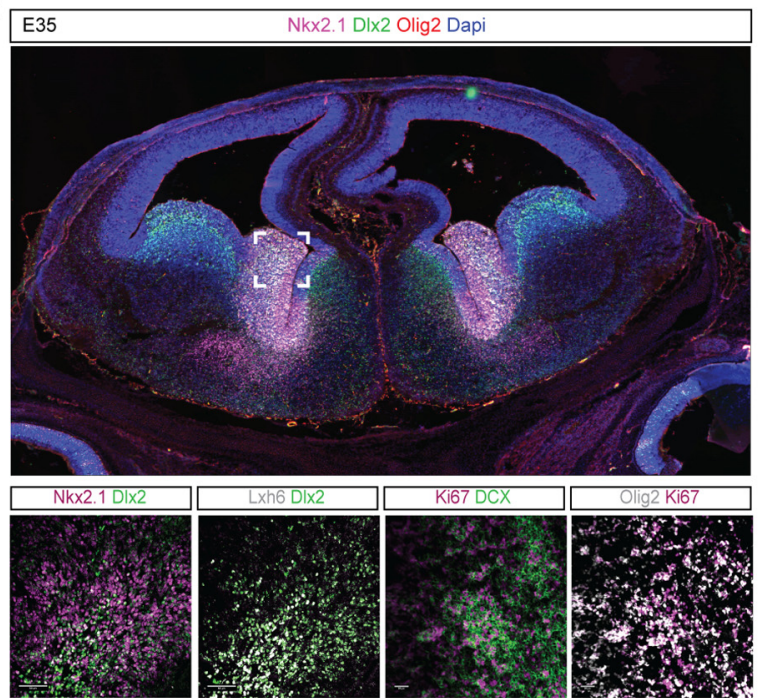

C

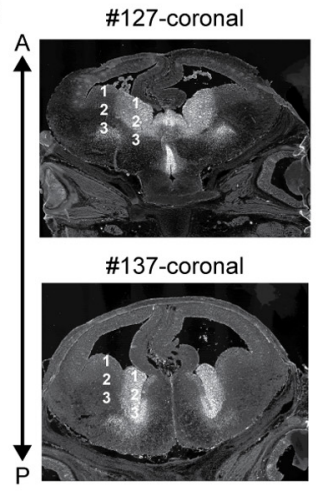

b

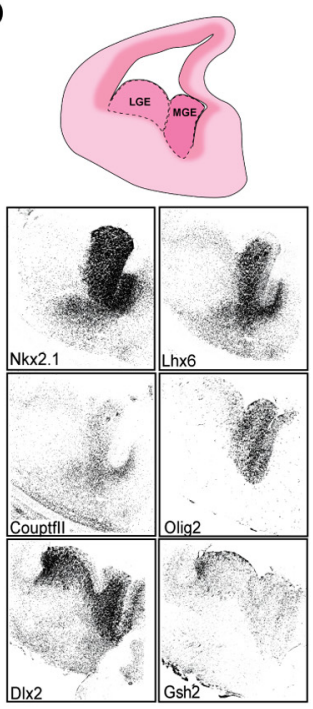

PH5 \#137-1 coronal

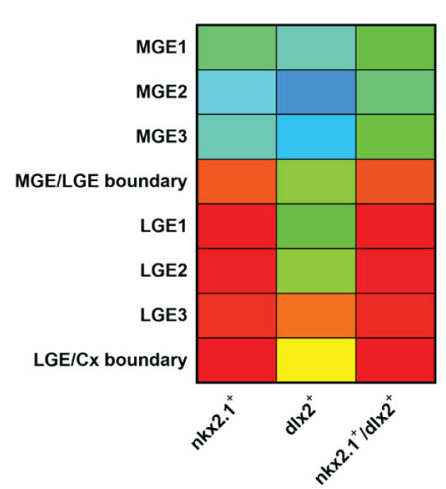

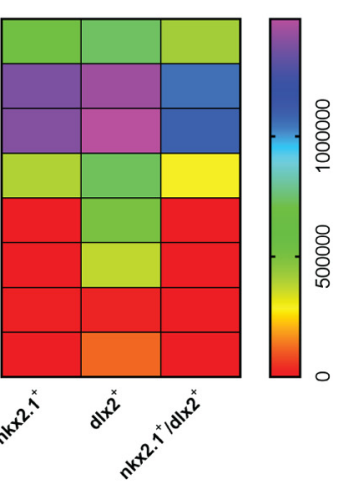

Figure 3. Demarcation of an embryonic MGE subregion in the developing pig brain. $\boldsymbol{a}$, Coexpression of Nxk2.1, Dlx2, and Olig2 in a representative coronal brain section at E35 (top). Higher-resolution images shown in bottom panels (box) highlight coexpression patterns for intermediate progenitors (Nkx2.1 and Dlx2), MGE-specific transcription factors (Lhx6 and Dlx2), proliferating and young neurons (Ki67 and DCX), or MGE-derived oligodendrocytes and proliferating cells (0lig2 and Ki67) $(n=9)$. $\boldsymbol{b}$, Schematic showing localization of MGE and LGE subregions on an equivalent section corresponding to the grayscale images (top). Transcription factor markers (Lhx6 and Dlx2) label the porcine MGE (marked by Nkx2.1). Olig2 expression is also prominent in MGE. Couptfll expression overlaps with migratory cells exiting the MGE. Gsh2 expression in VZ regions is most prominently in LGE $(n=18)$. c, Representative coronal sections (\#127 and \#137) along the anterior to posterior at $300 \mu \mathrm{m}$ are shown at E35 brain. Nxk2.1 ${ }^{+}$-, Dlx2 ${ }^{+}$-, and Nkx2.1:Dlx2 ${ }^{+}$-expressing cells were counted. MGE and LGE subregions, designated 1-3, were used for cell density measurements (in cell $/ \mathrm{s} / \mathrm{cm}^{2}$ ). Left, Heatmaps of these GE region cell density measurements. Heatmap color scale $=0-150,000$ cells $/ \mathrm{cm}^{2}(n=18)$.

Image processing and cell quantification

Images were acquired from fluorescently labeled sections using Keyence B7-X710, Leica Microsystems TCS SP5 or Nikon Eclipse Ni-E confocal microscopes. For whole-brain visualization, images were acquired using a $10 \times$ objective in Tilescan mode on a Keyence microscope with $Z$ stack to focus automatic stitching of arrayed tiles. Live imaging movies were acquired on a Leica Microsystems TCS SP5 using $10 \times$ objective, $1.5 \times$ optical zoom in time intervals of $20 \mathrm{~min}$. All labeled cells were counted using FIJI (http://imagej.net) by an investigator blind to the status of the experiment. Gray level intensity was set using thresholded binary images in FIJI Watershed.

\section{Experimental design and statistical analysis}

Cell culture. MGE was dissociated into single cells using neuronal isolation enzyme mix, as described previously. A $50 \mu$ drop of $10 \%$ FBS in NIM (DMEM Ff12, NEAA 1:100, N2 1×, heparin 1:1000, B27 1×, EGF, FGF) containing $5000 \mathrm{cells} / \mathrm{cm}^{2}$ was placed onto a polyornithine/ laminin-coated coverslip in 24-well plate for $4 \mathrm{~h}$ to allow initial attachment. An additional $100 \mu \mathrm{l}$ of $10 \%$ FBS in NIM was added for ON incubation and further attachment of cells to the coverslip. The next morning, all media containing FBS was removed, and fresh NIM with no FBS with factors (BDNF, GDNF, IGF, and cAMP 1:5000 v/v) was added to start the differentiation process. Cells were allowed to differentiate for $14 \mathrm{~d}$ with media change every $48 \mathrm{~h}$. Factors were freshly added to the media. After cells reached desired differentiation stage, they were fixed in $4 \%$ PFA for $5 \mathrm{~min}$ at RT and stored in $0.1 \%$ sodium azide $(w / v)$ in PBS for histology.

Xenotransplantation. MGE was identified by anatomic landmarks and freshly dissected, as described previously (Hunt et al., 2013; Casalia et al., 2017) (see Fig. 9). Tissue was then cryopreserved in 10\% DMSO in DMEM/F12 using $1.5 \mathrm{ml}$ cryotubes and stored in a liquid nitrogen tank between $-210^{\circ} \mathrm{C}$ and $-196^{\circ} \mathrm{C}$. On the day of xenotransplantation, cryotubes were quickly thawed under running warm water with gentle shaking. Neuronal Isolation Enzyme mix (Pierce, \#88285E) was used for cell dissociation (30 min at $37^{\circ} \mathrm{C}$ ). Cell viability on freshly thawed cells was assessed using Trypan Blue; only MGE progenitor cells with $\geq 80 \%$ viability were processed for xenotransplantation. Rats were anesthetized with $1.5 \%-2.5 \%$ isoflurane in oxygen $(\mathrm{v} / \mathrm{v})$ and secured in a stereotaxic frame (Kopf, model 900). In a series of pilot studies, several needle sizes and cell volumes were tested (see Fig. 10). A protocol using single-cell suspension of 50,000 cells in $0.5 \mu \mathrm{l}$ of DMEM/F12 loaded into a $32 \mathrm{G}$ blunt Hamilton syringe was chosen. Target coordinates for stratum radiatum of hippocampal CA3 subfield were initially verified in a series of pilot dye injections $(n=3)$ at the following stereotaxic coordinates relative to bregma: AP -3.4, ML $\pm 2.7, \mathrm{DV}-3.4$. Cell deposits were made using an automatic microinjection pump (WPI Microinjection System, UMP3) at a rate of $5 \mathrm{nl} / \mathrm{s}$. The needle remained in place for $60 \mathrm{~s}$ and then was slowly withdrawn. Following xenotransplantation, the incision was closed with Vetbond (3M, \#1469SB), and rats were placed under a heat lamp until fully recovered. A successful porcine MGE xenotransplant was defined post hoc using histologic techniques, namely, the presence of at least $40 \mathrm{GFP}^{+}$cells in a minimum of 2 sections of the hippocampus $(25-\mu \mathrm{m}$-thick sections, spaced $300 \mu \mathrm{m}$ apart).

Explant assay. MGE was dissected and further subdissected in four sections (anterior-dorsal/anterior-ventral/posterior-dorsal/ posterior-ventral; see Fig. 6). Each subsection was submerged in a Matrigel drop (Corning, \#356237) containing 50\% of cell culture media (Neurobasal, $1 \times$ amphotericin, $1 \times$ penicillin-streptomycin, $1 \times$ glutaMAX) and placed onto a Matrigel-coated coverslip of a 24 -well plate at $37^{\circ} \mathrm{C}$ under hypoxic conditions $\left(5 \% \mathrm{CO}_{2}, 8 \% \mathrm{O}_{2}\right.$ balanced $\mathrm{N}_{2}$ ). Explants were allowed to attach $\mathrm{ON}$ with addition of $10 \%$ FBS to cell culture media. The next morning, media containing FBS was removed and replaced with serum-free media. Explants were kept in vitro for $6 \mathrm{~d}$ with media change every $48 \mathrm{~h}$. At the end of the process, each coverslip was carefully washed 3 times with PBS and fixed for $15 \mathrm{~min}$ in $4 \%$ PFA in PBS solution for histologic analysis.

Slice culture. E35 brains were removed out of the head in cold DMEM F12 media. Tissue was embedded in 3.5\% low melting point agarose in $310 \mathrm{mOsm}$ ACSF $(125 \mathrm{~mm} \mathrm{NaCl}, 2.5 \mathrm{~mm} \mathrm{KCl}, 1 \mathrm{~mm} \mathrm{MgCl}, 2 \mathrm{~mm}$ $\mathrm{CaCl}_{2}, 1.25 \mathrm{~mm} \mathrm{NaH}_{2} \mathrm{PO}_{4}, 25 \mathrm{~mm}$ glucose, bubbled with $95 \% \mathrm{O}_{2} / 5 \%$ 
$\mathrm{CO}_{2}$ ) and sliced using a Leica Microsystems VT1200S vibratome at $300 \mu \mathrm{m}$ thickness. Sections were allowed to stabilize for $20 \mathrm{~min}$ in bubbling ACSF on ice before being transferred and suspended on $0.4 \mu \mathrm{m}$ Millicell$\mathrm{CM}$ slice culture inserts (Millipore). Sections were cultured for $6 \mathrm{~d}$ at $37^{\circ} \mathrm{C}$ in $5 \% \mathrm{CO}_{2}, 8 \% \mathrm{O}_{2}$, and balanced $\mathrm{N}_{2}$. For time-lapse imaging, an adenovirus (AV-CMVGFP, $1 \times 10^{10}$; Vector Biolabs) at a dilution of 1:501:500 was applied to the slices, which were then cultured at $37^{\circ} \mathrm{C}, 5 \% \mathrm{CO}_{2}, 8 \% \mathrm{O}_{2}$. For time-lapse imaging, cultures were then transferred to an inverted Leica Microsystems TCS SP5 confocal microscope with an on-stage incubator streaming $5 \% \mathrm{CO}_{2}, 5 \% \mathrm{O}_{2}$, and balanced $\mathrm{N}_{2}$ into the chamber. Slices were imaged using a $10 \times$ air objective at $20 \mathrm{~min}$ intervals for $72 \mathrm{~h}$ with repositioning of the $z$ stacks every 6-8 $\mathrm{h}$.

Statistics

Data are expressed as mean \pm SEM. Statistical significance was assessed using one- or two-way ANOVA with Kruskal-Wallis multiple comparisons. $p<0.05$ was considered significant.

\section{Results}

Temporal and regional identification of porcine embryonic MGE

Across several species (Lavdas et al., 1999; Metin et al., 2007; Tanaka et al., 2011; Gelman et al., 2012; Hansen et al., 2013; Ma et al., 2013; Hu et al., 2017), GEs consisting of extensive proliferative cell masses are visible as distinct elevations adjacent to, and protruding into, lateral ventricular walls. Identification of embryonic lateral and medial GE subregions is guided by transient developmental appearance of anatomic landmarks (Brazel et al., 2003; Flames et al., 2007). In serial sections, an expansion of porcine embryonic forebrain occurs between E30 and E35 along with formation of a clear morphologic boundary (e.g., a sulcus in the ventricular surface separating LGE and MGE; Fig. 1). GE subregions can also be identified based on temporal transcription factor expression patterns. Nkx2.1, a homeobox transcription factor gene, is required for MGE specification and highly expressed in early MGE ventricular zones (VZs) (Corbin et al., 2003; Du et al., 2008; Sandberg et al., 2016). At E30 and E35, we observed prominent anterior-to-posterior $\mathrm{Nkx} 2.1$ expression coinciding with appearance of a sulcus and anatomic designation of an MGE subregion (Fig. 1 $a$, arrows); absence of expression in LGE and caudal ganglionic eminence (CGE) was also noted (Fig. 1b). Gsh2 (also known as Gsx2), another homeobox transcription factor gene, is critical for dorsalventral patterning of telencephalon and diffusely expressed throughout GE domains (Flames et al., 2007; Du et al., 2008). Coronal sections at E30 show diffuse expression of Gsh2 throughout porcine embryonic GE while evolving to more restricted expression patterns corresponding to CGE and LGE ventricular proliferative zone regions at E35 (Fig. $1 a, b$, white arrows). Olig2, a basic helix-loop-helix transcription factor gene, is expressed in progenitor cells of ventral GE with highest levels in Nkx2.1-expressing MGE subregions (Miyoshi et al., 2007). At E35, Olig2 expression is prominent in proliferative

a

b
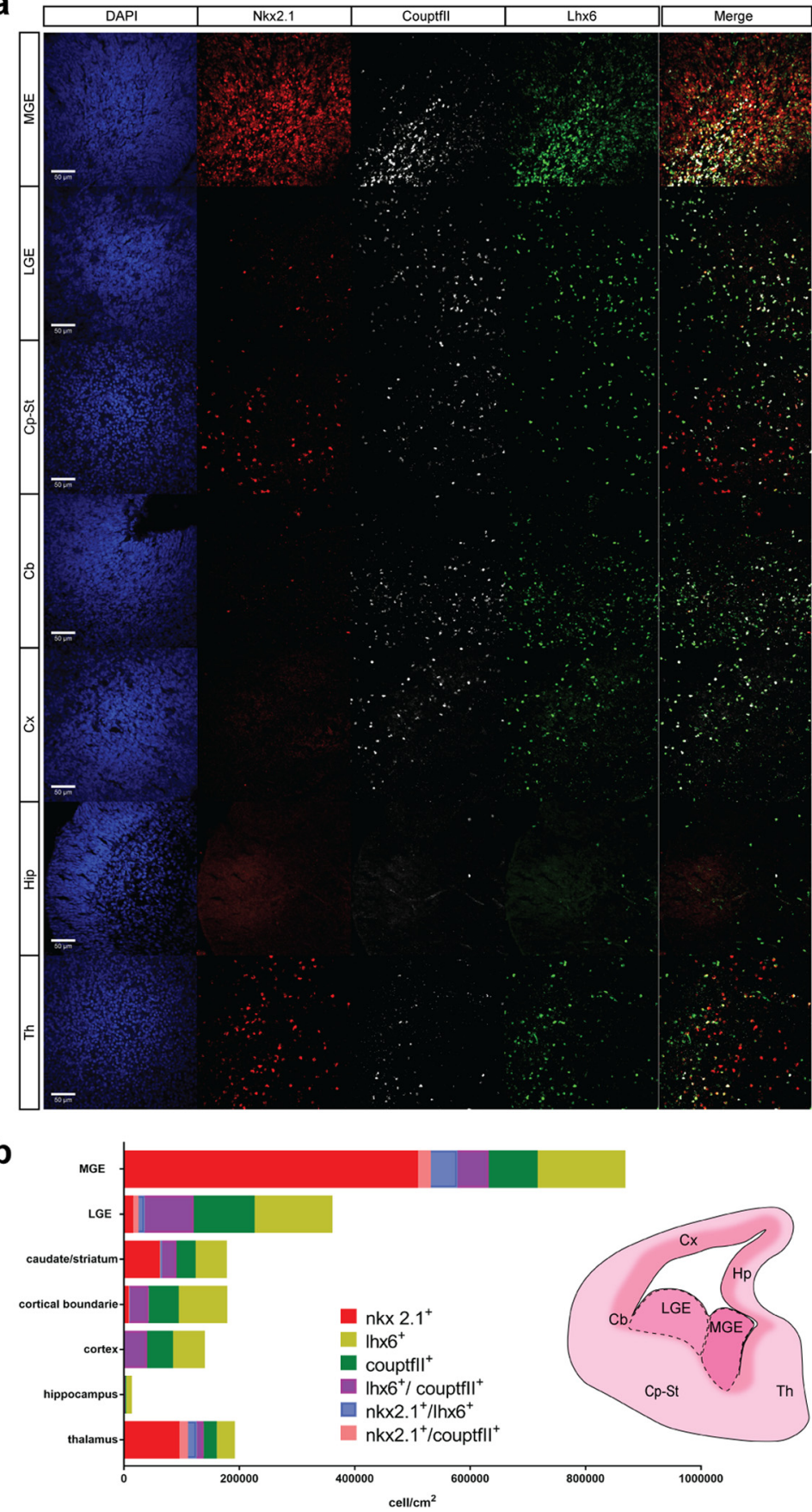

Figure 4. MGE-derived progenitor cell distribution in porcine embryonic subpallium. $\boldsymbol{a}$, Representative Nkx2.1, Couptfll, and Lhx6 expression patterns in porcine at E35 are shown. DAPI stain and merged images are also shown $(n=9)$. Scale bar, $100 \mu \mathrm{m}$. b, Grouped summary data plots showing transcription factor (Nxk2.1, Lhx6, and Couptfll) cell densities (cell/ $/ \mathrm{cm}^{2}$ ) for embryonic subregions shown in schematic (right). Coexpression quantification is also shown for Lhx6:Couptfll ${ }^{+}$, Nkx2.1:Lhx6 ${ }^{+}$, and Nkx2.1:Couptfll ${ }^{+}$cells in these subregions $(n=7)$. (p-St, Caudate putamen-striatum; Cb, cortical boundary; Cx, cortex; Hip, hippocampus; Th, Thalamus.

zones of porcine MGE with only sparse expression in CGE or LGE (Fig. 1b). Dlx homeobox transcription factors (Dlx1/2 and Dlx5/6), widely expressed throughout subpallium, are broadly required for GE progenitors to migrate and differentiate into GABAergic interneurons (Flames et al., 2007; Du et al., 2008; Laclef and Metin, 2018). Porcine Dlx2 expression at E35 is prominent in MGE (and CGE), though somewhat less dense along ventricular proliferative zones. LGE expression is more diffuse presumably because interneuron progenitors begin migration 
a
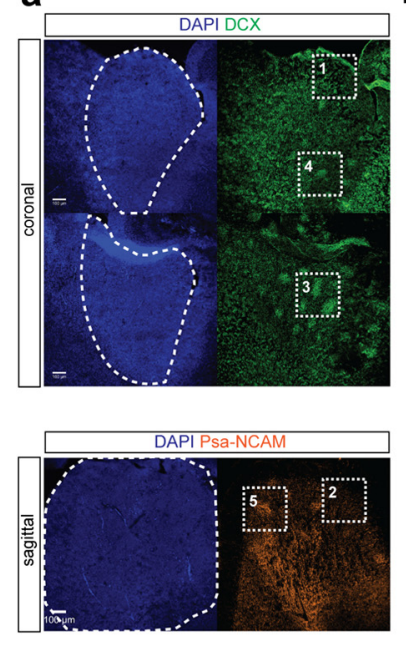

b

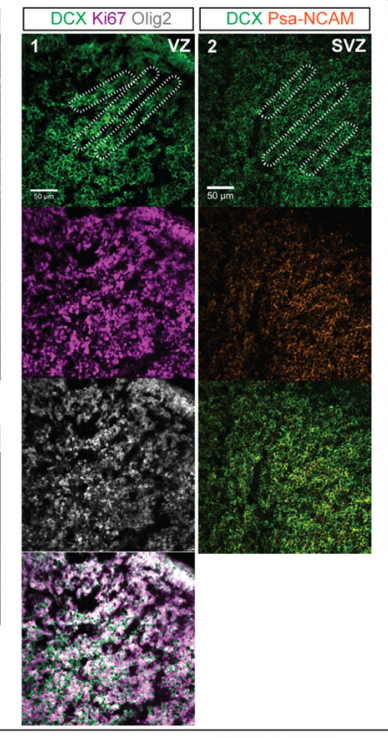

c

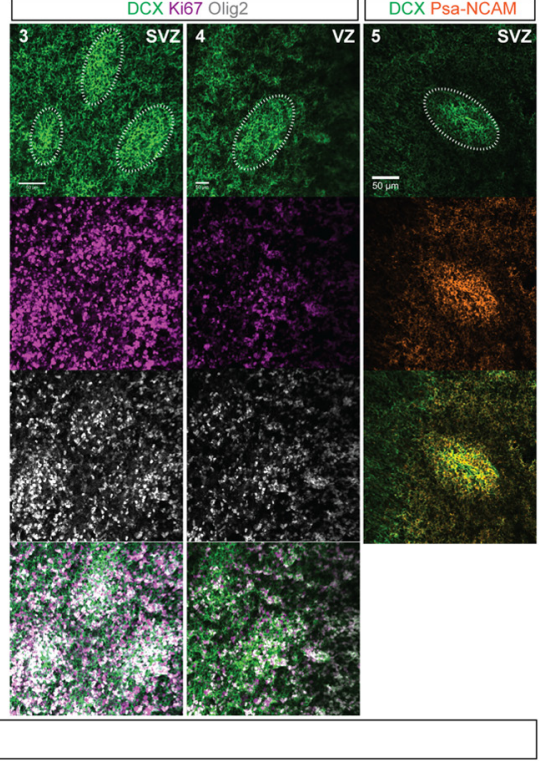

Figure 5. Organization of $D C X^{+}$clusters in embryonic porcine MGE at E35. $\boldsymbol{a}$, Representative coronal and sagittal sections showing DCX clustering in the MGE (designated by white boundary). Left, Note DCX ${ }^{+}$or Psa-NCAM ${ }^{+}$cell organization. $\boldsymbol{b}$, Magnified images of boxed areas in $\boldsymbol{a}$ show organization of cells coexpressing Ki67 and 0lig2 (\#1) or DCX and Psa-NCAM (\#2). c, Magnified images of boxed areas in a show clusters of cells coexpressing DCX, Ki67, and Olig2 (\#3, \#4, SVZ and VZ, respectively) or DXC and Psa-NCAM (\#5). Scale bar, $50 \mu \mathrm{m} . n=18$.

toward cortical areas at this stage of embryonic development. Optical density measurements on coronal sections confirm high levels of Dlx2 and Olig2 expression in all three VZs of porcine MGE at E30 and E35 (Fig. 1c). Lhx6, an LIM homeodomain transcription factor, activated by Nkx2.1, also plays a critical role in specification of MGE-derived interneuron subtypes (Grigoriou et al., 1998; Du et al., 2008). Lhx6, expressed in MGE subventricular zone (SVZ) and submantle zone, is required for differentiation of $\mathrm{PV}^{+}$and $\mathrm{SOM}^{+}$interneurons. At E30, we observed significant Lhx6 expression as a column of migrating cells bordering VZs, contiguous with basal MGE and beginning to populate piriform cortex ventrally and LGE laterally (Fig. $2 a$, coronal and sagittal). Dlx2 shows a similar coexpression pattern, but overall density is less in piriform cortex and scattered expression in VZs was noted. At E35, Lhx6 expression in presumably migratory cells outside the MGE VZ is more prominent ventrally (Fig. $2 a$, coronal) along with scattered expression into intermediate zones of LGE and cortex (Fig. $2 a$, coronal and sagittal; Fig. $3 b$ ). Dlx2 expression at E35 is prominent in MGE and LGE subregions. Nkx2.1 coexpression with Lhx6 or Dlx2 can be seen in most cells within the MGE ventricular proliferative zone at E35 (Fig. 2b1, coronal; Fig. 3a) but only a few cells in more intermediate zones (Fig. 2b2, sagittal). Serial coronal sections along the anterior-to-posterior axis (Fig. $2 c$ ) reveal distinct Lhx6 expression in presumed tangential telencephalon-tocortex, telencephalon-to-striatum, telencephalon-to-olfactory bulb migratory streams, as previously described in mice (Marin and Rubenstein, 2001; Alifragis et al., 2004; Liodis et al., 2007); Lhx6 coexpression with Dlx2 was also noted in MGE (Fig. 3a). In medial coronal sections at E35, MGE (marked by intense Nkx2.1 and Lhx6 expression) coexpressed Dlx2 and Olig2 more densely than LGE (Fig. 3a,b). Expression of CouptfII (an orphan nuclear receptor enriched in CGE) (Kanatani et al., 2008) was expressed in dorsal MGE, as expected (Cai et al., 2013); Gsh2 (enriched in LGE/ CGE) (Du et al., 2008; Laclef and Metin, 2018), was not prominent in MGE (Fig. 3b). Nonspecific ventral forebrain progenitor markers (Ki67, Olig2, and DCX) label porcine MGE at E35 with dense coexpression of Olig2 and Ki67 noted (Fig. $3 a$ ).

Next, we performed a compartmentalized quantitative analysis of Nxk2.1- and Dlx2-expressing cells using coronal sections representative of anterior or posterior levels of E35 porcine MGE. MGE and LGE were divided into three subregions starting at the ventricular surface (MGE1) as well as boundary regions for MGE/LGE or LGE/cortex (Fig. 3c). In the most anterior section (Fig. 3c; PH5 \#127-1), Nkx2.1 cell density is highest in MGE regions 1 and 2 corresponding to proliferative VZs, and extending into subregion 3 of the most posterior section (Fig. 3c; PH5 $\# 137-1)$. At a posterior level, Nkx2.1 cell density drops off at the MGE/LGE boundary and is absent from LGE and LGE/cortex boundaries. Dlx2 cell density is high throughout all MGE proliferative zones and subregions, MGE/LGE boundary, and into LGE subregions 1 and 2 (Fig. 3c). As expected (Flames et al., 2007; Long et al., 2009), coexpression of cells expressing Nkx2.1 and Dlx2 cells was restricted to MGE at both levels.

It is well established that MGE produces GABAergic neurons that tangentially migrate to hippocampus, cortex, striatum, and thalamus (Marin and Rubenstein, 2001; Metin et al., 2007; Laclef and Metin, 2018). Next, we used downregulation of Nkx2.1 expression in migratory cells to delineate MGE regions coupled with Lhx6 expression to track migratory cells and the transition between germinal zone and migratory routes at E35 (Fig. 4). Large populations of $\mathrm{Nkx} 2.1^{+}$progenitor cells were observed in MGE, with additional $\mathrm{Nkx} 2.1^{+}$cells migrating into caudatestriatum and thalamus. $\mathrm{Nkx} 2.1^{+}$cell density greatly decreased in LGE consistent with downregulation of this transcription factor after leaving MGE (Marin and Rubenstein, 2001); Nkx2.1 $1^{+}$cells were not observed in cortex or hippocampus. A significant population of $\mathrm{Lhx}^{+}$cells can be seen in dorsal MGE along with CouptfII ${ }^{+}$cells (Fig. 4). Outside MGE, similar patterns of Lhx6 ${ }^{+}$ and CouptfII ${ }^{+}$cells can be seen in caudate-striatum, thalamus, and cortex, suggesting a corridor for tangential migration. Distinct nonoverlapping populations of $\mathrm{Nkx}^{2} \cdot 1^{+}$and $\mathrm{Lhx} 6^{+}$/ 
CouptfII ${ }^{+}$cells are present in caudateputamen and thalamus. Together, these observations support a conclusion that temporal, morphologic, and molecular characteristics of embryonic MGE are conserved in the pig.

At E35, we also noted a unique organization of $\mathrm{DCX}^{+}$cells originating close to the ventricle in $\mathrm{VZ}$ or SVZ regions of porcine MGE (Fig. 5a,b, inset 1). Organization of MGE progenitor cells into clusters was described for human and primate (but not murine) embryonic brains (Hansen et al., 2013; $\mathrm{Ma}$ et al., 2013). Some coexpression with a marker of young proliferative Ki67 ${ }^{+}$ cells was observed in these $\mathrm{DCX}^{+}$clusterlike formations. These cells extended transversally toward outer ventricular areas with coexpression of Psa-NCAM, a neural cell adhesion molecule regulating maturation of GABAergic interneurons (Fig. $5 a, b$, inset 2). More distinct oval-shaped clusters were seen in outer VZ and SVZ further from the ventricular surface (Fig. 5a,c, insets 3-5). Oval-shaped clusters were densely populated by a core of $\mathrm{DCX}^{+} / \mathrm{Ki}^{+}$proliferative young neurons and clear coexpression of Olig2 and Psa-NCAM.

In vitro migration and characterization of porcine MGE Embryonic MGE progenitor cells exhibit chain migration when cultured in a three-dimensional extracellular matrix gel (Matrigel) (Wichterle et al., 1997, 2003). Using the same explant protocol, E35 porcine MGE sections were placed in Matrigel drops and kept under hypoxic conditions for 6 DIV. Extensive migration from MGE explants, forming an outer ring of cells emerging from the core, was seen as early as $3 \mathrm{DIV}$, and grew more extensive by 6 DIV (Fig. $6 a$, yellow arrow). Outside this band, cells were loosely arranged forming a meshwork of migrating cell chains emanating from the explant core in all directions (Fig. $6 a$, magenta arrow) and reaching distant areas of the plate (Fig. 6a, magenta arrowhead). Cells migrating outward from explants coexpressed the following: (1) DCX, a microtubuleassociated protein expressed by neuronal progenitor cells and immature neurons; and (2) Lhx6, an MGE-specific transcription factor (Fig. $6 a$, middle, bottom). $\mathrm{DCX}^{+}$cells had an elongated morphology resembling those described for migrating mouse MGE cells in vitro (Wichterle et al., 1997). We also observed robust individual cell migration in time-lapse movies obtained from E35 porcine MGE tissue slices cultured in vitro for $48 \mathrm{~h}$ (Movie 1). To quantify migration capacity, MGE explants were subdivided into anterior or posterior and dorsal or ventral regions (anterior-dorsal/anterior-ventral/posterior-dorsal/posterior-ventral), and individual cell distance from explants was measured (Fig. 6b, schematic). As expected (Wichterle et al., 1997, 2003), migration was robust in every subregion (Fig. 6b).

\section{In vitro differentiation of MGE progenitor cells}

Under appropriate induction protocols (Franchi et al., 2018), MGE progenitors differentiate into cortical or hippocampal GABAergic neurons in vitro. Therefore, porcine MGE cells were cultured in

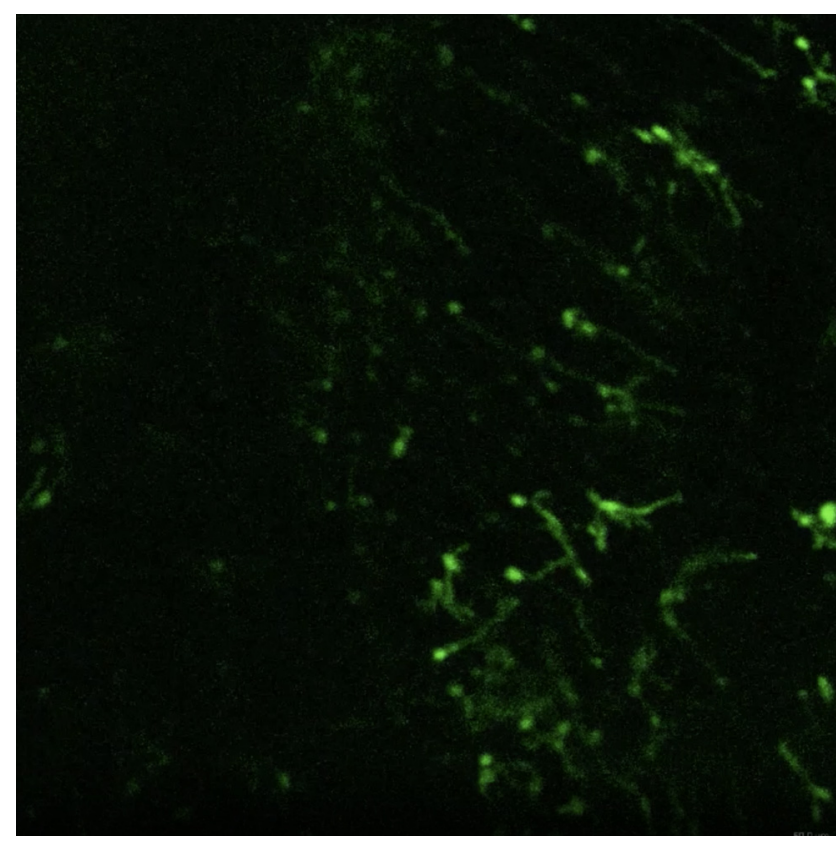

Movie 1. Time-lapse movie of lentivirus-labeled pig MGE. Time-lapse movie showing migrating (green) MGE neurons in a cultured embryonic pMGE tissue slice at E35 ( $n=3$ experiments). [View online]

vitro to evaluate molecular maturation. Cells dissected from E35 porcine MGE were plated onto polyornithine laminin-coated dishes and cultured as monolayers. Immunohistochemical analysis was performed on day 14 (Fig. 7a). Many cells with mature neuronal morphologies and extensive processes coexpressed neurofilament (NF70) and neuron-specific Class III $\beta$-tubulin (e.g., antigen for the Tuj1 antibody), a marker of immature and mature 
a
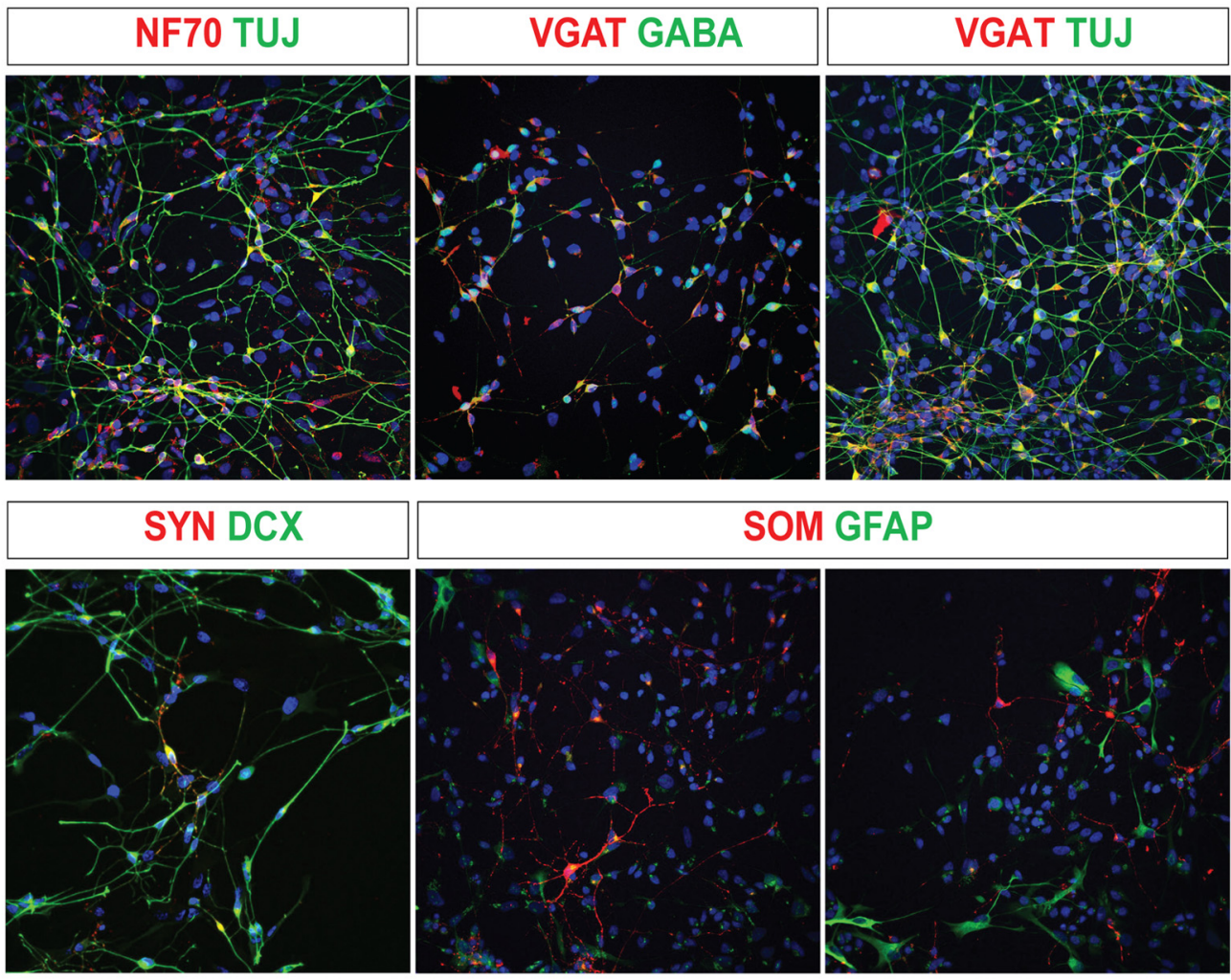

SOM GFAP

b
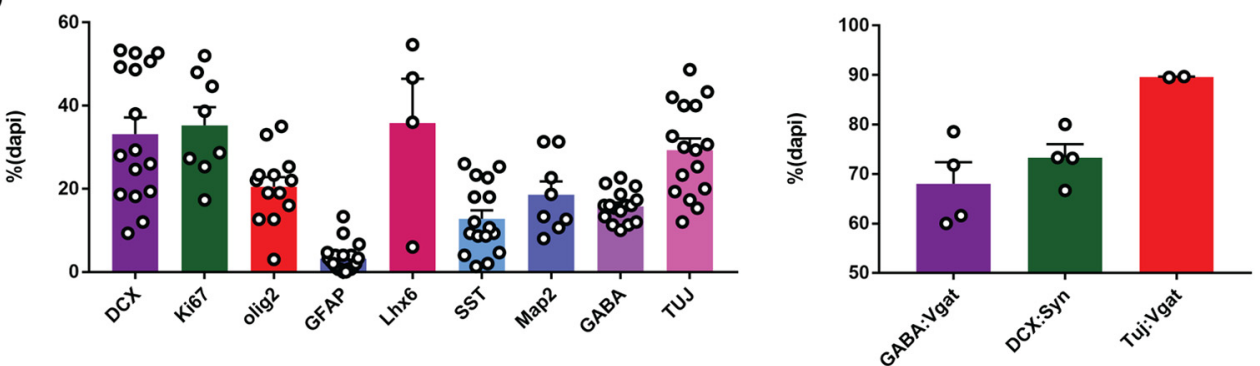

Figure 7. Characterization of porcine MGE progenitor cells in vitro. $\boldsymbol{a}$, Representative images of MGE-derived cells immunolabeled with markers of neuronal maturation (NF70, neurofilament; TUJ, neuron-specific Class III $\beta$-tubulin) and DCX, interneurons (GABA, SOM, or VGAT), astrocytes (GFAP), or presynaptic terminals (SYN). Images were collected at $14 \mathrm{~d}$ in culture. $\boldsymbol{b}$, Quantification of expression plotted as a \% over DAPI stain. Data are mean \pm SEM ( $n=3$ or more independent experiments).

neurons. MGE-derived cells with complex neuronal morphologies expressed markers of inhibitory interneurons, namely, GABA and a vesicular GABA transporter (VGAT). Consistent with an MGE identity, cells also expressed OLIG2 (20.5\%), LHX6 (35.8\%), and SOM (12.8\%) (Fig. 7a,b). Many cells expressed DCX, a marker for young migratory neurons (Fig. 7a,b). Cells with neuronal morphologies also expressed synaptophysin (SYN), a synaptic vesicle protein and MAP2, a dendritic marker. Only a very small number of MGEderived cells expressed GFAP (3.3\%), an astrocytic marker. Undifferentiated stem cells were still present at this point in culture as indicated by expression of Ki67 (35.3\%), a proliferative cell marker. The majority of interneuron-like $\mathrm{GABA}^{+}$cells coexpress VGAT (GABA:VGAT $=68 \%$ ) or neuron-specific Class III $\beta$-tubulin (TUJ:VGAT $=89.6 \%$ ); significant coexpression of DCX and SYN was also noted (DCX:SYN =73.3\%) (Fig. 7c).

\section{Xenotransplantation of pig MGE in adult rats}

Using embryonic brain slices (Anderson et al., 1997; Marin et al., 2000), in utero fate mapping (Wichterle et al., 2001), Matrigel explant assays (Wichterle et al., 1997, 2003), and in vivo transplantation (Wichterle et al., 1999; Alvarez-Dolado et al., 2006; Hunt et al., 2013), it is now well established that postnatal brain is permissive for migration and integration of transplanted embryonic murine MGE progenitors. To establish an efficient method for xenotransplantation and assessment of porcine MGE progenitors in a host brain, MGE was dissected from transgenic E35 pig embryos expressing GFP. GFP expression was used to track migration and differentiation following transplantation into hippocampus of recipient adult WT Sprague Dawley rats $(n=75$; Table 1$)$. At $30 \mathrm{DAT}, \mathrm{GFP}^{+}$cells dispersed into most hippocampal subregions in dorsal and ventral directions with widespread distribution in dentate gyrus and CA1 (Fig. 8a,b). Distribution of porcine MGE-derived cells in host hippocampus increased between 7 and $14 \mathrm{DAT}$, reaching a relative plateau up to 60 DAT (Fig. $8 b$ ). Porcine MGE-derived GFP ${ }^{+}$cells in hippocampus differentiated into cells resembling mature interneuron morphologies (e.g., bipolar cells, basket cells, and multipolar cells) with elaborate dendritic trees and axonal projections (Fig. 
a

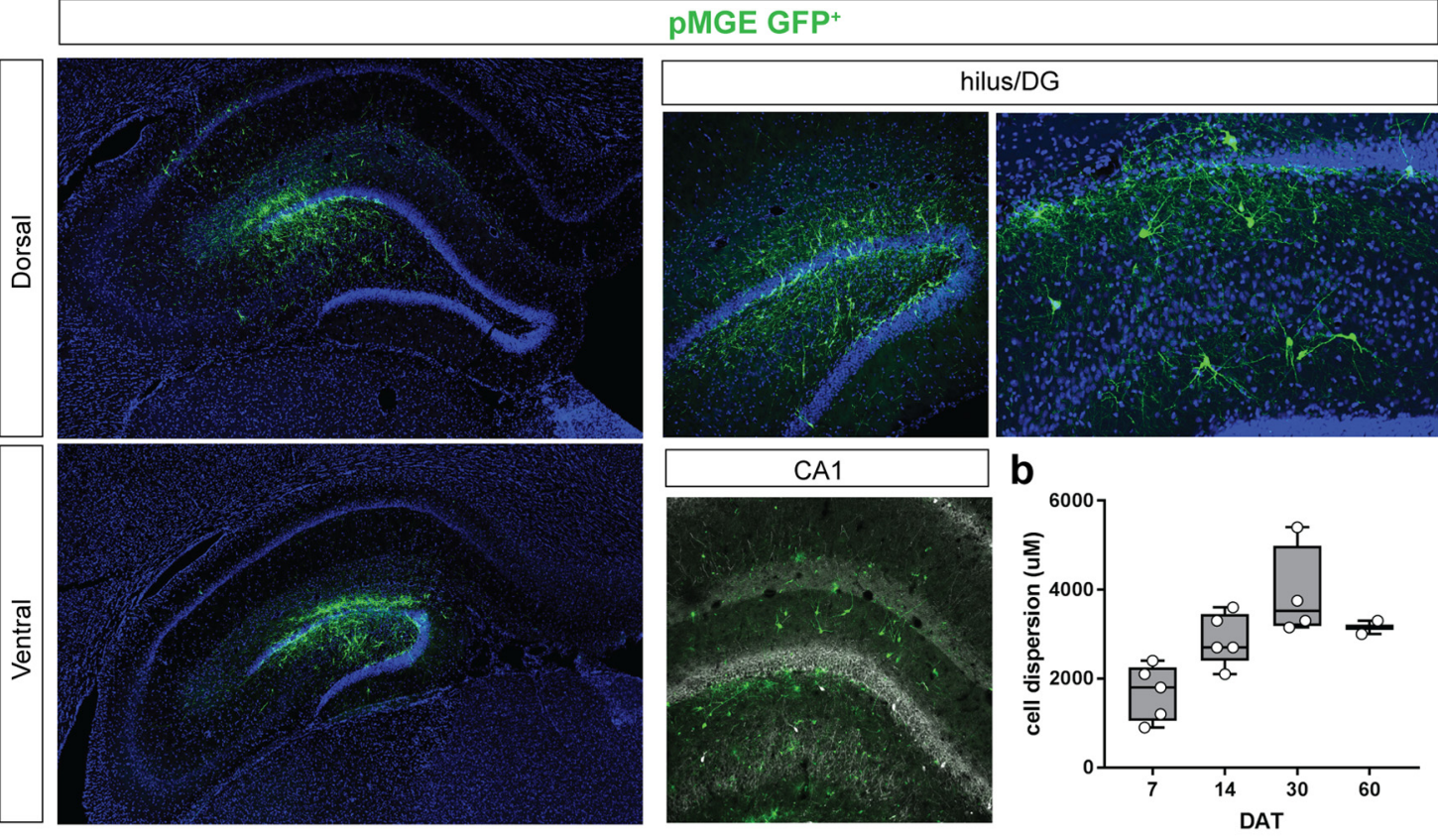

C
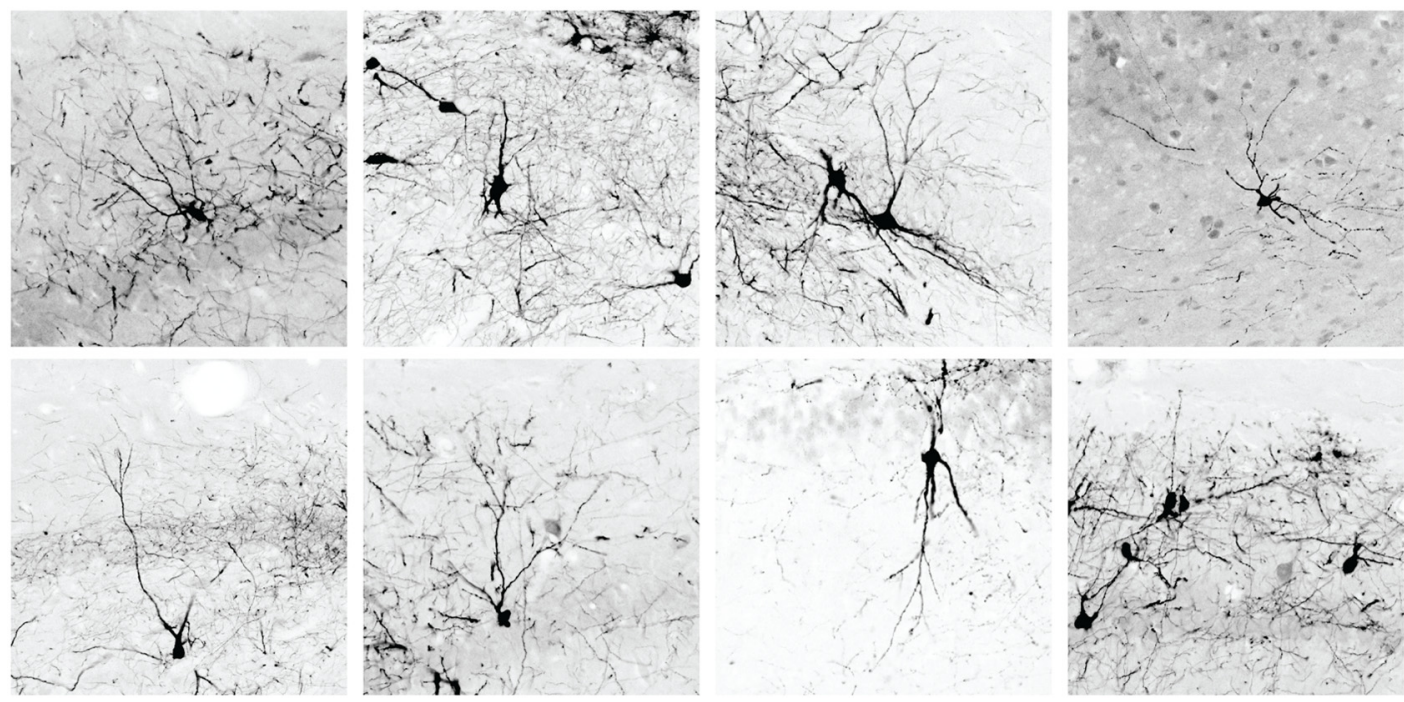

Figure 8. Distribution of porcine MGE-derived cells in the adult rat brain. $\boldsymbol{a}$, Hippocampus of adult Sprague Dawley rat recipients 60 DAT labeled for DAPI (blue) and GFP ${ }^{+}$transplanted porcine (p) MGE-derived neurons (green). MGE cells dispersed after xenotransplantation into recipient rats populating dorsal and ventral hippocampus locations. Higher-magnification images show $\mathrm{GFP}^{+}$cells in the rat hilus/dentate gyrus (DG) and CA1 subregions. $\boldsymbol{b}, \mathrm{GFP}^{+}$cell dispersion along the anterior-to-posterior axis of the rat hippocampus at 7, 14, 30, and $60 \mathrm{DAT}(n=3$ or more independent experiments). c, Porcine MGE-derived cells in the rat hippocampus differentiated into neurons presenting typical morphology of interneuron subtypes (e.g., bitufted, multipolar, and basket).

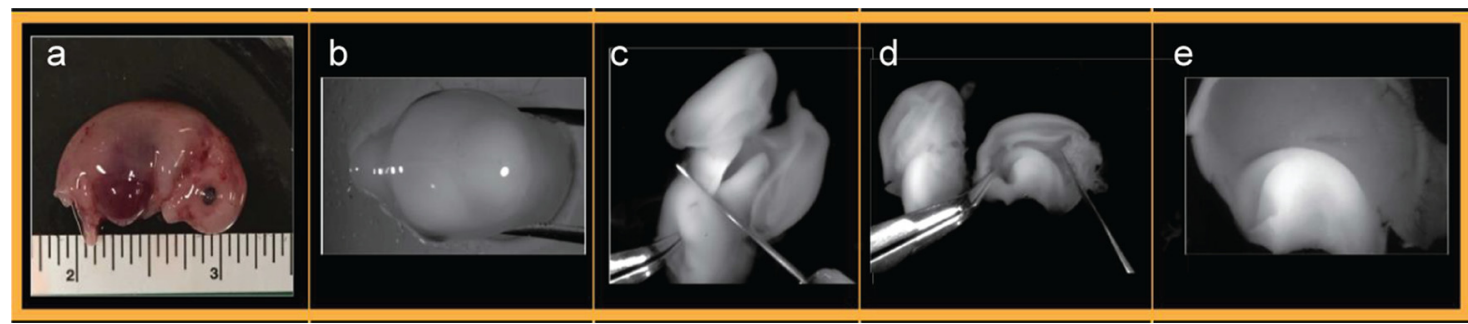

Figure 9. Dissection protocol for porcine MGE at E35. $\boldsymbol{a}$, Intact pig embryo. $\boldsymbol{b}$, Pig head viewed from the top. $\boldsymbol{c}$, Isolated pig brain with first posterior cut to isolate forebrain. $\boldsymbol{d}$, Isolated pig brain micro-dissected into right and left hemispheres. Isolated right hemisphere has GE exposed. $\boldsymbol{e}$, Higher-magnification image to view exposed GE region of right hemisphere. 
a

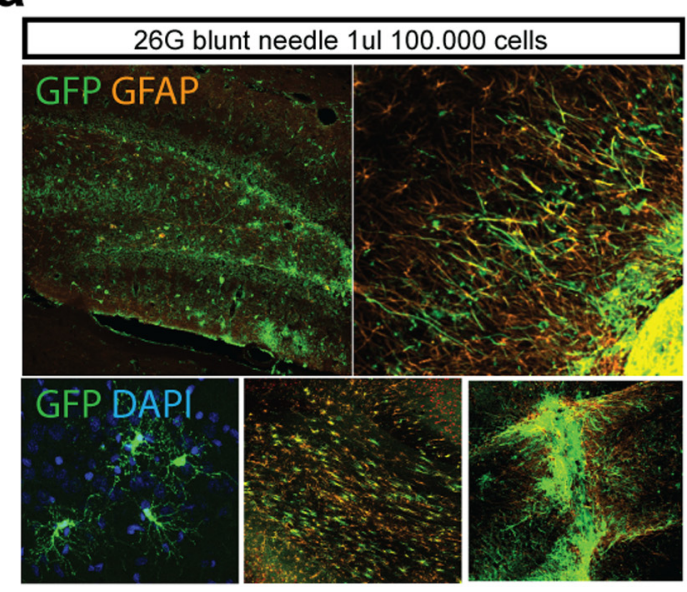

b

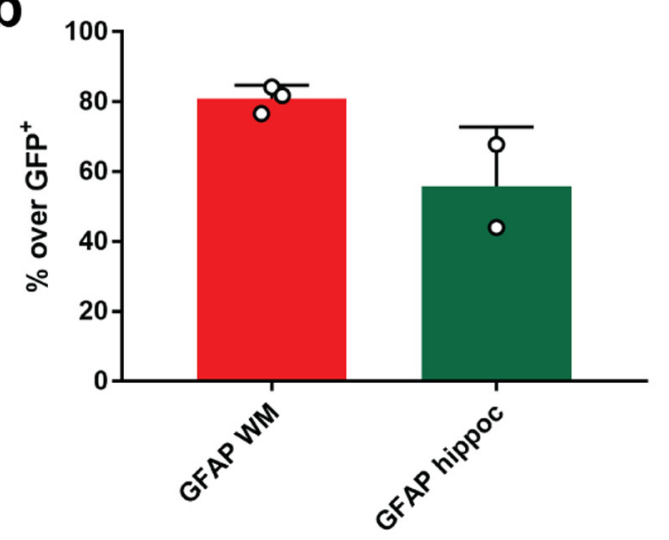

C
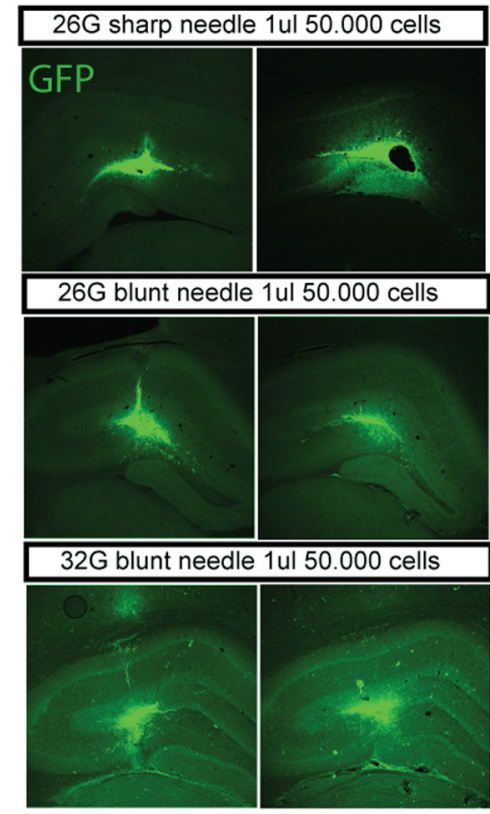

32G blunt needle 0.5 ul 50.000 cells

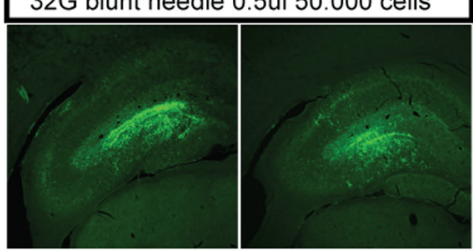

d

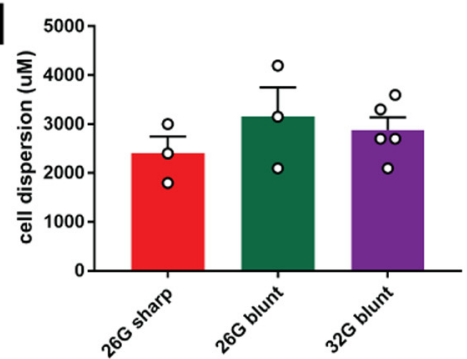

e
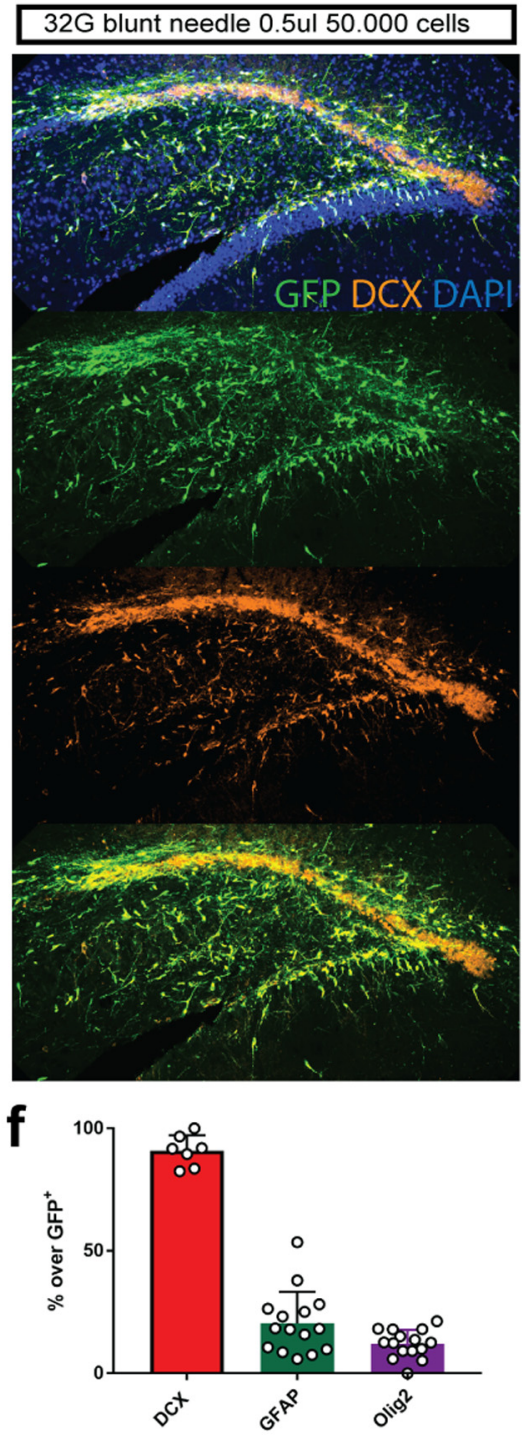

Figure 10. Optimization of porcine MGE xenotransplant protocol. A range of needle gauge sizes, injection volumes, and cell densities were tested ( $n=3$ independent experiments per manipulation). $\boldsymbol{a}$, A total of 100,000 porcine MGE GFP ${ }^{+}$(green) cells in $1 \mu$ l transplanted into adult rat hippocampus using a $26 \mathrm{G}$ blunt Hamilton needle. Note the dense expression of GFAPexpressing MGE cells at 14 DAT (top). Higher magnification shows GFP ${ }^{+}$cells with astrocytic morphology (bottom left). Also, note the high density of GFP:GFAP ${ }^{+}$cells in fimbria and white matter tracts adjacent to hippocampus (bottom middle). The injection site also shows a dense concentration of GFP ${ }^{+}$cells unable to migrate out and astrocytes invading the needle tract (bottom right). $\boldsymbol{b}$, Plot represents quantification of GFP:GFAP ${ }^{+}$cells in white matter tract (80.9\%) adjacent to hippocampus and inside hippocampus (55.9\%). Data are mean \pm SEM. $\boldsymbol{c}$, Representative images of the adult hippocampus (14 DAT) with GFP-labeled pMGE cells transplanted at varying injection needle gauges, injection volumes, and cell densities. $\boldsymbol{d}$, Note the dense core of $\mathrm{GFP}^{+}$cells near the injection site. Plot represents limited dispersion of GFP:GFAP ${ }^{+}$cells in hippocampus. Data are mean \pm SEM. $\boldsymbol{e}, \mathrm{A}$ total of 50,000 porcine MGE GFP ${ }^{+}$(green) cells in $0.5 \mu \mathrm{l}$ transplanted into adult rat hippocampus using a $32 \mathrm{G}$ blunt Hamilton needle. Note the dispersion of GFP ${ }^{+}$cells from the injection site and GFP:DCX ${ }^{+}$neurons at 14 DAT. $f$, Plot represents \% of GFP ${ }^{+}$cells coexpressing DCX (90.9\%), GFAP (20.5\%), or Olig2 (12.1\%).

$8 c$ ). None of the porcine MGE-derived neurons exhibited morphologic features of cortical pyramidal neurons (e.g., triangular cell soma extending a thick spiny apical dendrite). No tumors were observed in any host animal (Figs 9, 10).

MGE-derived interneurons can be identified by expression of the neurotransmitter GABA and neuropeptides, such as SOM or PV (Fishell, 2007; Gelman et al., 2012; Laclef and Metin, 2018). Double immunofluorescence revealed that most $\mathrm{GFP}^{+}$porcine MGE-derived cells express GABA between 14 and 60 DAT. $\mathrm{GFP}^{+}$cells exhibited increased subtype-specific SOM coexpression that also correlated with time after transplantation. By 60 DAT, the percentage of SOM:GFP ${ }^{+}$cells significantly increased to $26.6 \%$ (Fig. 11). $\mathrm{PV}^{+}$pMGE-derived neurons in the recipient rat brain could not be detected with available antibodies (see Materials and Methods). Tuj1 was present in $\mathrm{GFP}^{+}$cells at 30 and 60 DAT. GFP ${ }^{+}$cells expressing Olig2 (20.5\%) were primarily localized to injection sites, and only a small subpopulation express GFAP (4.7\%) (Fig. 12).

\section{Discussion}

Here, we present strong evidence that porcine progenitors in embryonic MGEs express Nkx2.1, Lhx6, and Dlx2. In vitro, porcine MGE progenitor cells exhibit robust migratory properties and 


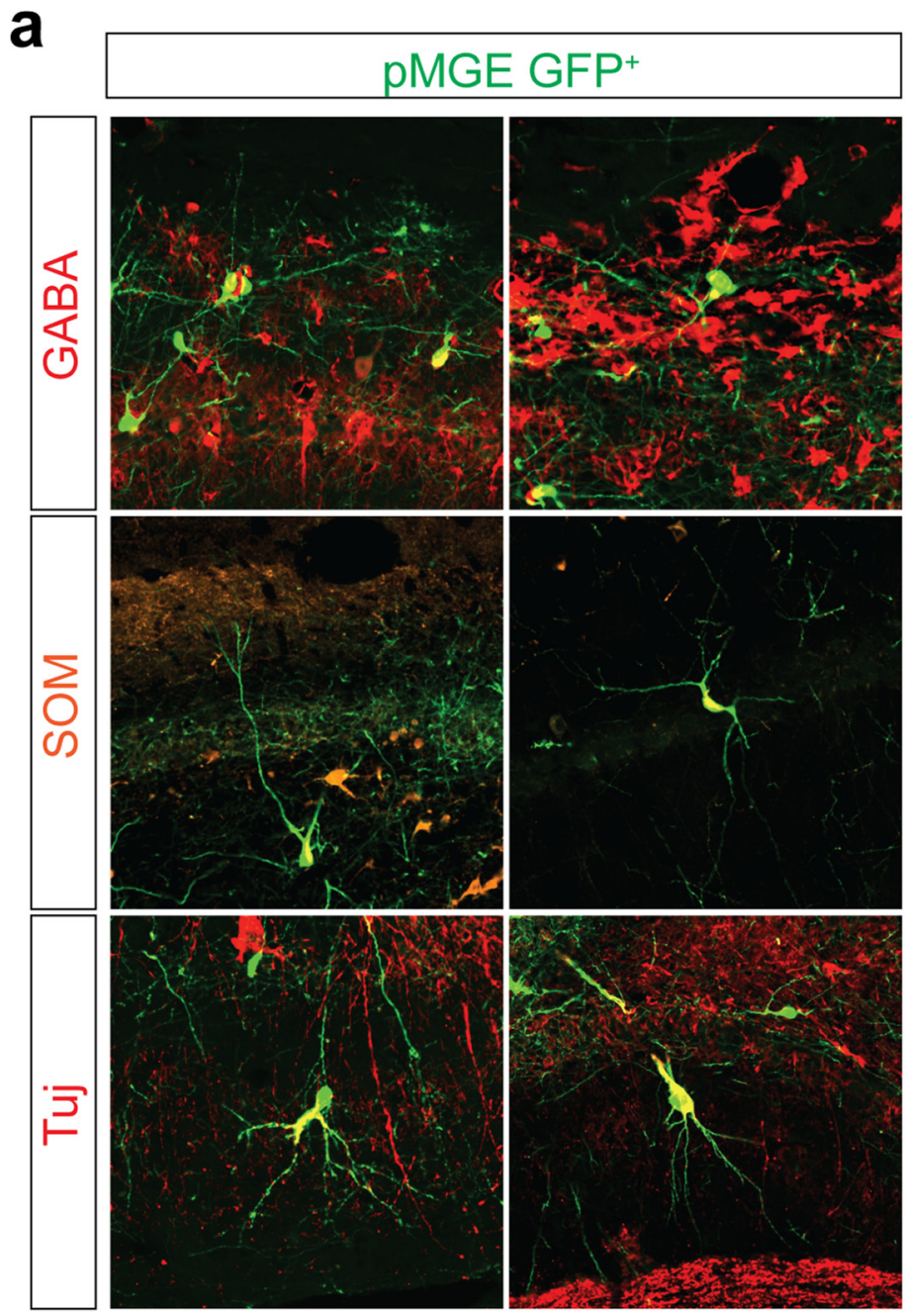

\section{b}
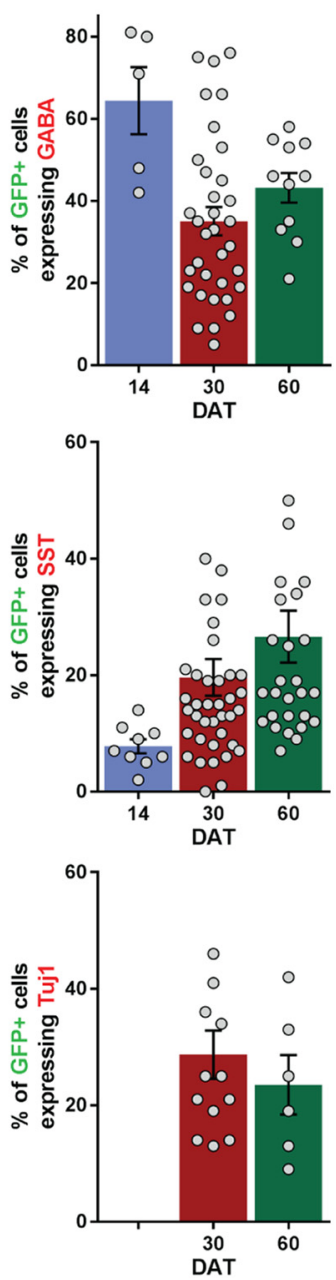

Figure 11. Immunohistochemical characterization of pMGE-derived cells in the adult rat brain. $\boldsymbol{a}$, Coexpression of GFP-labeled MGE-derived cells (green) with markers for inhibitory interneurons (GABA and SOM) or a neuronal marker (Tuj). $\boldsymbol{b}$, Quantification of pMGE-derived GFP ${ }^{+}$cells coexpressing each marker at 14, 30, and 60 DAT. SOM 7 versus 60 DAT: $F_{(2,32)}=3.902$; $p=0.0345$, one-way ANOVA. Data are mean \pm SEM ( $n=3$ or more independent experiments).

differentiate to neurons expressing GABA, vGAT, and SOM. Following xenotransplantation into adult rat hippocampus, porcine MGE progenitors migrate extensively and differentiate to neurons with mature morphologies coexpressing GABA and SOM. Thus, porcine MGE progenitors may offer a valuable source of new inhibitory neurons for the types of transplantation-based therapeutic applications already suggested for mouse MGE progenitors (e.g., epilepsy, Alzheimer's disease, and traumatic brain injury) (Baraban et al., 2009; Anderson and Baraban, 2012; Hunt et al., 2013; Tong et al., 2014; Zhu et al., 2019).

The transcription factor profiles, migratory behavior (in vitro and in vivo), and differentiation into inhibitory interneurons observed in our porcine studies are remarkably similar to that described for mouse, monkey, or human MGE. Seminal studies described a subpallial origin of cortical and hippocampal interneurons in rodents (Anderson et al., 1997; Marin et al., 2000; Pleasure et al., 2000), and a primary role of MGE in producing a subpopulation of interneurons has been extensively reviewed (Wonders and Anderson, 2006; Fishell, 2007; Gelman et al., 2012). From this work, several families of transcription factors controlling subpallial embryonic development and fate of interneurons originating in MGE are well established. These include Lhx6, Olig2, Dlx1/2, and Nkx2.1 in embryonic subpallial MGE
(Du et al., 2008; Laclef and Metin, 2018) and Lhx6 in migrating MGE-derived cortical interneurons (Alifragis et al., 2004; Liodis et al., 2007; Vogt et al., 2014). It has also been demonstrated, through comparative analyses of gene expression patterns in chick, frog, zebrafish, lamprey, monkey, and human, that basic developmental organization of the embryonic subpallium and interneuron MGE origin is conserved across species (Hauptmann and Gerster, 2000; Puelles et al., 2000; Brox et al., 2004; Molnár et al., 2006; Cheung et al., 2007; Pombal et al., 2011; Hansen et al., 2013; Ma et al., 2013; Pauly et al., 2014). Our observations are entirely consistent with these descriptions.

In contrast to an earlier "failed" attempt to expand MGEderived neurons in vitro from primary cells (Chen et al., 2013), our studies more closely replicate those of Franchi et al. (2018), showing that in vitro differentiation of rodent MGE progenitors into cortical or hippocampal interneurons involves outgrowth and elaboration of dendritic and axonal arbors (Fig. 7). Similarly, most cells become GABAergic as indicated by coexpression of the inhibitory neurotransmitter GABA and presynaptic marker vGAT. At 14 DIV, porcine MGE cells also mimic the dense network of MAP2-positive dendrites and expression of a postsynaptic marker (SYN) seen with rodent cultures. Unlike murine 


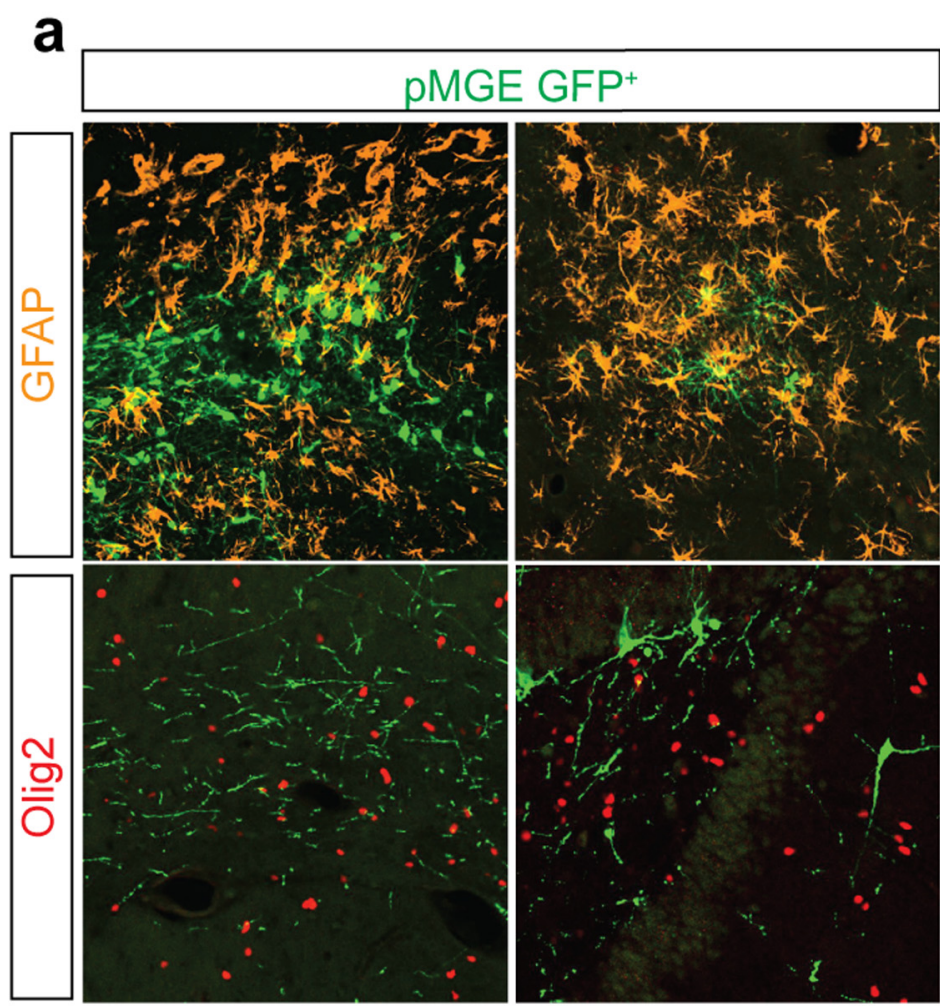

b
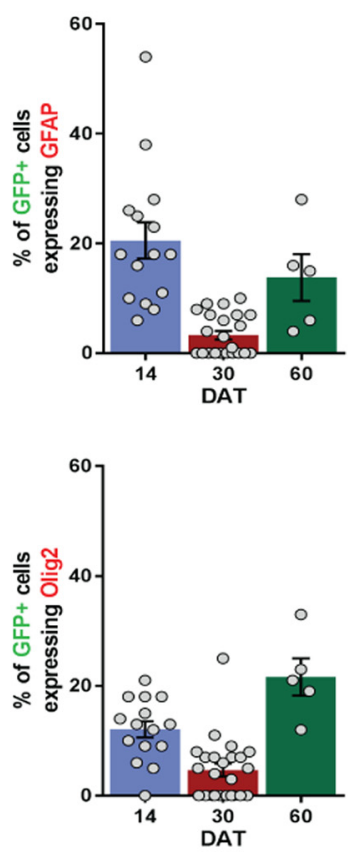

Figure 12. Immunohistochemical characterization of porcine MGE-derived cells in the adult rat brain. $\boldsymbol{a}$, Coexpression of GFP-labeled MGE-derived cells (green) with markers for astrocytes (GFAP) or oligodendrocytes (0lig2). $\boldsymbol{b}$, Quantification of MGE-derived GFP ${ }^{+}$cells coexpressing each marker at 14,30 , and 60 DAT. Data are mean \pm SEM ( $n=3$ or more independent experiments).

MGE, porcine MGE exhibited unique organization of $\mathrm{DCX}^{+}$ cells. This feature of porcine embryonic subpallium is reminiscent of human fetal brain sections (Hansen et al., 2013) and suggests a conservation of neurodevelopmental programs between pig and human not seen in rodents. It has been suggested that segregation into distinct cell clusters facilitates tangential migration of interneuron progenitors in developing brain, a process that, at the molecular level, may be regulated by expression of cell adhesion molecules, such as fibronectin leucine-rich repeat transmembrane protein (Seiradake et al., 2014; del Toro et al., 2017) or transmembrane ephrin-B proteins (Zimmer et al., 2011; Dimidschstein et al., 2013). As such, further experimental analysis of porcine embryonic development could provide more direct insights into mechanisms underlying interneuron migration in higher species.

Another key attribute widely attributed to MGE progenitors is a capacity for migration (Wichterle et al., 1999). While most neuronal progenitors migrate through anatomically discontinuous cell-poor and cell-rich environments using radial glial scaffolds, chain migration allows migration of young GABAergic neurons through cell-dense regions independent of radial glial. Based on this unique migration capacity, MGE progenitors transplanted into cortex, hippocampus, striatum, or even spinal cord, early in postnatal development or adult brain, retain a migratory capacity (Wichterle et al., 1999; Alvarez-Dolado et al., 2006; Baraban et al., 2009; Martínez-Cerdeño et al., 2010; Bráz et al., 2012; Hunt et al., 2013; Casalia et al., 2017). Taking advantage of these properties, MGE progenitor cell transplantation has shown remarkable therapeutic capacity in preclinical animal models of epilepsy (Baraban et al., 2009; Hunt et al., 2013; Casalia et al., 2017), traumatic brain injury (Zhu et al., 2019), Alzheimer's disease (Tong et al., 2014), Parkinson's disease
(Martínez-Cerdeño et al., 2010), and neuropathic pain (Bráz et al., 2012; Juarez-Salinas et al., 2019). Here we used a xenotransplantation protocol to demonstrate that porcine MGE progenitors maintain this migratory capacity following transplantation into adult rat hippocampus. Robust migration was seen up to 60 DAT with cells differentiating to mature interneurons with complex dendritic arborizations and expression of antibodies marking MGE-specific inhibitory cell populations (e.g., GABA and SOM). Only a relatively small number of cells expressed markers for astrocytes (GFAP); and unlike human "MGE-like" stem cellderived interneurons (Carpentino et al., 2008), we never observed tumors. Previous work transplanting mouse MGE progenitors also consistently shows neurons expressing GABA and SOM (Alvarez-Dolado et al., 2006; Baraban et al., 2009; Hunt et al., 2013; Tong et al., 2014; Casalia et al., 2017; Zhu et al., 2019). While early postnatal MGE mouse transplant studies (and these vary by recipient brain region) report $\mathrm{PV}^{+}$neurons also consistent with an MGE lineage, $\mathrm{PV}^{+}$cells take longer to develop and make up a smaller population of MGE-derived neurons in adult intrahippocampal transplant studies (Hunt et al., 2013; Casalia et al., 2017). We also noted that, unlike same-species allograft murine-to-murine MGE transplant studies where immunosuppression protocols were unnecessary, even with a cocktail of immunosuppressants a pig-to-rat xenotransplantation protocol was only successful in about half of the animals. Not unexpected, as similar xenotransplant studies evaluating the fate of MGE-like human cells only used SCIDimmunodeficient mice as host animals (Maroof et al., 2013; Nicholas et al., 2013). The myriad immunoreactive processes that could take place, even in a relatively protected environment such as the CNS, remain to be optimized for these types of xenotransplantation studies. We anticipate that future 
studies will address these factors and perhaps use CRISPRbased gene editing technologies (Cowan et al., 2019; Hryhorowicz et al., 2020) to generate donor pig embryos ideally suited to this purpose.

\section{References}

Alifragis P, Liapi A, Parnavelas JG (2004) Lhx6 regulates the migration of cortical interneurons from the ventral telencephalon but does not specify their GABA phenotype. J Neurosci 24:5643-5648.

Alvarez-Buylla A, Herrera DG, Wichterle H (2000) The subventricular zone: source of neuronal precursors for brain repair. Prog Brain Res 127:1-11.

Alvarez-Dolado M, Calcagnotto ME, Karkar KM, Southwell DG, Jones-Davis DM, Estrada RC, Rubenstein JL, Alvarez-Buylla A, Baraban SC (2006) Cortical inhibition modified by embryonic neural precursors grafted into the postnatal brain. J Neurosci 26:7380-7389.

Anderson SA, Baraban SC (2012) Cell therapy using GABAergic neural progenitors. Jasper's basic mechanisms of the epilepsies (Noebels JL, Avoli M, eds). Oxford University Press: Bethesda, MD.

Anderson SA, Eisenstat DD, Shi L, Rubenstein JL (1997) Interneuron migration from basal forebrain to neocortex: dependence on Dlx genes. Science 278:474-476.

Baraban SC, Southwell DG, Estrada RC, Jones DL, Sebe JY, Alfaro-Cervello C, Garcia-Verdugo JM, Rubenstein JL, Alvarez-Buylla A (2009) Reduction of seizures by transplantation of cortical GABAergic interneuron precursors into Kv1.1 mutant mice. Proc Natl Acad Sci USA 106:15472-15477.

Björklund A, Dunnett SB, Brundin P, Stoessl AJ, Freed CR, Breeze RE, Levivier M, Peschanski M, Studer L, Barker R (2003) Neural transplantation for the treatment of Parkinson's disease. Lancet Neurol 2:437-445.

Bráz JM, Sharif-Naeini R, Vogt D, Kriegstein A, Alvarez-Buylla A, Rubenstein JL, Basbaum AI (2012) Forebrain GABAergic neuron precursors integrate into adult spinal cord and reduce injury-induced neuropathic pain. Neuron 74:663-675.

Brazel CY, Romanko MJ, Rothstein RP, Levison SW (2003) Roles of the mammalian subventricular zone in brain development. Prog Neurobiol 69:49-69.

Brox A, Puelles L, Ferreiro B, Medina L (2004) Expression of the genes Emx1, Tbr1, and Eomes (Tbr2) in the telencephalon of Xenopus laevis confirms the existence of a ventral pallial division in all tetrapods. J Comp Neurol 474:562-577.

Cai Y, Zhang Q, Wang C, Zhang Y, Ma T, Zhou X, Tian M, Rubenstein JL, Yang Z (2013) Nuclear receptor COUP-TFII-expressing neocortical interneurons are derived from the medial and lateral/caudal ganglionic eminence and define specific subsets of mature interneurons. J Comp Neurol 21:479-497.

Carpentino JE, Hartman NW, Grabel LB, Naegele JR (2008) Region-specific differentiation of embryonic stem cell-derived neural progenitor transplants into the adult mouse hippocampus following seizures. J Neurosci Res 86:512-524.

Casalia ML, Howard MA, Baraban SC (2017) Persistent seizure control in epileptic mice transplanted with gamma-aminobutyric acid progenitors. Ann Neurol 82:530-542.

Chen YJ, Vogt D, Wang Y, Visel A, Silberberg SN, Nicholas CR, Danjo T, Pollack JL, Pennacchio LA, Anderson S, Sasai Y, Baraban SC, Kriegstein AR, Alvarez-Buylla A, Rubenstein JL (2013) Use of 'MGE enhancers' for labeling and selection of embryonic stem cell-derived medial ganglionic eminence (MGE) progenitors and neurons. PLoS One 8:e61956.

Cheung AF, Pollen AA, Tavare A, DeProto J, Molnár Z (2007) Comparative aspects of cortical neurogenesis in vertebrates. J Anat 211:164-176.

Corbin JG, Rutlin M, Gaiano N, Fishell G (2003) Combinatorial function of the homeodomain proteins Nkx2.1 and Gsh2 in ventral telencephalic patterning. Development 130:4895-4906.

Cowan PJ, Hawthorne WJ, Nottle MB (2019) Xenogeneic transplantation and tolerance in the era of CRISPR-Cas9. Curr Opin Organ Transplant 24:5-11

Cox ET, Brennaman LH, Gable KL, Hamer RM, Glantz LA, Lamantia AS, Lieberman JA, Gilmore JH, Maness PF, Jarskog LF (2009) Developmental regulation of neural cell adhesion molecule in human prefrontal cortex. Neuroscience 162:96-105.
Del Toro D, Ruff T, Cederfjall E, Villalba A, Seyit-Bremer G, Borrell V, Klein R (2017) Regulation of cerebral cortex folding by controlling neuronal migration via FLRT adhesion molecules. Cell 169:621-635.

Dimidschstein J, Passante L, Dufour A, van den Ameele J, Tiberi L, Hrechdakian T, Adams R, Klein R, Lie DC, Jossin Y, Vanderhaeghen P (2013) Ephrin-B1 controls the columnar distribution of cortical pyramidal neurons by restricting their tangential migration. Neuron 79:11231135 .

Donegan JJ, Tyson JA, Branch SY, Beckstead MJ, Anderson SA, Lodge DJ (2017) Stem cell-derived interneuron transplants as a treatment for schizophrenia: preclinical validation in a rodent model. Mol Psychiatry 22:1492-1501.

Du T, Xu Q, Ocbina PJ, Anderson SA (2008) NKX2.1 specifies cortical interneuron fate by activating Lhx6. Development 135:1559-1567.

Fishell G (2007) Perspectives on the developmental origins of cortical interneuron diversity. Novartis Found Symp 288:21-35; discussion 35-44, 9628.

Flames N, Pla R, Gelman DM, Rubenstein JL, Puelles L, Marin O (2007) Delineation of multiple subpallial progenitor domains by the combinatorial expression of transcriptional codes. J Neurosci 27:9682-9695.

Franchi SA, Macco R, Astro V, Tonoli D, Savino E, Valtorta F, Sala K, Botta M, de Curtis I (2018) A method to culture GABAergic interneurons derived from the medial ganglionic eminence. Front Cell Neurosci 11:423.

Gelman DM, Marin O, Rubenstein JL (2012) The generation of cortical interneurons. Jasper's basic mechanisms of the epilepsies (Noebels JL, Avoli M, eds). Bethesda, MD.

Grigoriou M, Tucker AS, Sharpe PT, Pachnis V (1998) Expression and regulation of Lhx6 and Lhx7, a novel subfamily of LIM homeodomain encoding genes, suggests a role in mammalian head development. Development 125:2063-2074

Hansen DV, Lui JH, Flandin P, Yoshikawa K, Rubenstein JL, lvarez-Buylla A, Kriegstein AR (2013) Non-epithelial stem cells and cortical interneuron production in the human ganglionic eminences. Nat Neurosci 16:15761587.

Hauptmann G, Gerster T (2000) Regulatory gene expression patterns reveal transverse and longitudinal subdivisions of the embryonic zebrafish forebrain. Mech Dev 91:105-118.

Hryhorowicz M, Lipiński D, Hryhorowicz S, Nowak-Terpiłowska A, Ryczek N, Zeyland J (2020) Application of genetically engineered pigs in biomedical research. Genes (Basel) 11:670.

Hu JS, Vogt D, Sandberg M, Rubenstein JL (2017) Cortical interneuron development: a tale of time and space. Development 144:3867-3878.

Hunt RF, Girskis KM, Rubenstein JL, Alvarez-Buylla A, Baraban SC (2013) GABA progenitors grafted into the adult epileptic brain control seizures and abnormal behavior. Nat Neurosci 16:692-697.

Inan M, Petros TJ, Anderson SA (2013) Losing your inhibition: linking cortical GABAergic interneurons to schizophrenia. Neurobiol Dis 53:36-48.

Jacoby DB, Lindberg C, Cunningham MG, Ratliff J, Dinsmore J (1999) Longterm survival of fetal porcine lateral ganglionic eminence cells in the hippocampus of rats. J Neurosci Res 56:581-594.

Juarez-Salinas DL, Bráz JM, Etlin A, Gee S, Sohal V, Basbaum AI (2019) GABAergic cell transplants in the anterior cingulate cortex reduce neuropathic pain aversiveness. Brain 142:2655-2669.

Kanatani S, Yozu M, Tabata H, Nakajima K (2008) COUP-TFII is preferentially expressed in the caudal ganglionic eminence and is involved in the caudal migratory stream. J Neurosci 28:13582-13591.

Kessaris N, Magno L, Rubin AN, Oliveira MG (2014) Genetic programs controlling cortical interneuron fate. Curr Opin Neurobiol 26:79-87.

Laclef C, Metin C (2018) Conserved rules in embryonic development of cortical interneurons. Semin Cell Dev Biol 76:86-100.

Lavdas AA, Grigoriou M, Pachnis V, Parnavelas JG (1999) The medial ganglionic eminence gives rise to a population of early neurons in the developing cerebral cortex. J Neurosci 19:7881-7888.

Liodis P, Denaxa M, Grigoriou M, Akufo-Addo C, Yanagawa Y, Pachnis V (2007) Lhx6 activity is required for the normal migration and specification of cortical interneuron subtypes. J Neurosci 27:3078-3089.

Liu Y, Weick JP, Liu H, Krencik R, Zhang X, Ma L, Zhou GM, Ayala M, Zhang SC (2013) Medial ganglionic eminence-like cells derived from human embryonic stem cells correct learning and memory deficits. Nat Biotechnol 31:440-447. 
Long JE, Cobos I, Potter GB, Rubenstein JL (2009) Dlx1\&2 and Mash1 transcription factors control MGE and CGE patterning and differentiation through parallel and overlapping pathways. Cereb Cortex 19 Suppl 1:96106.

Ma T, Wang C, Wang L, Zhou X, Tian M, Zhang Q, Zhang Y, Li J, Liu Z, Cai Y, Liu F, You Y, Chen C, Campbell K, Song H, Ma L, Rubenstein JL, Yang Z (2013) Subcortical origins of human and monkey neocortical interneurons. Nat Neurosci 16:1588-1597.

Marin O (2012) Interneuron dysfunction in psychiatric disorders. Nat Rev Neurosci 13:107-120.

Marin O, Rubenstein JL (2001) A long, remarkable journey: tangential migration in the telencephalon. Nat Rev Neurosci 2:780-790.

Marin O, Anderson SA, Rubenstein JL (2000) Origin and molecular specification of striatal interneurons. J Neurosci 20:6063-6076.

Maroof AM, Keros S, Tyson JA, Ying SW, Ganat YM, Merkle FT, Liu B, Goulburn A, Stanley EG, Elefanty AG, Widmer HR, Eggan K, Goldstein PA, Anderson SA, Studer L (2013) Directed differentiation and functional maturation of cortical interneurons from human embryonic stem cells. Cell Stem Cell 12:559-572.

Martínez-Cerdeño V, Noctor SC, Espinosa A, Ariza J, Parker P, Orasji S, Daadi MM, Bankiewicz K, Alvarez-Buylla A, Kriegstein AR (2010) Embryonic MGE precursor cells grafted into adult rat striatum integrate and ameliorate motor symptoms in 6-OHDA-lesioned rats. Cell Stem Cell 6:238-250.

Metin C, Alvarez C, Moudoux D, Vitalis T, Pieau C, Molnár Z (2007) Conserved pattern of tangential neuronal migration during forebrain development. Development 134:2815-2827.

Miyoshi G, Butt SJ, Takebayashi H, Fishell G (2007) Physiologically distinct temporal cohorts of cortical interneurons arise from telencephalic Olig2expressing precursors. J Neurosci 27:7786-7798.

Molnár Z, Metin C, Stoykova A, Tarabykin V, Price DJ, Francis F, Meyer G, Dehay C, Kennedy H (2006) Comparative aspects of cerebral cortical development. Eur J Neurosci 23:921-934.

Nicholas CR, Chen J, Tang Y, Southwell DG, Chalmers N, Vogt D, Arnold CM, Chen YJ, Stanley EG, Elefanty AG, Sasai Y, Alvarez-Buylla A, Rubenstein JL, Kriegstein AR (2013) Functional maturation of hPSCderived forebrain interneurons requires an extended timeline and mimics human neural development. Cell Stem Cell 12:573-586.

Paterno R, Casalia M, Baraban SC (2020) Interneuron deficits in neurodevelopmental disorders: implications for disease pathology and interneuronbased therapies. Eur J Paediatr Neurol 24:81-88.

Pauly MC, Dobrossy MD, Nikkhah G, Winkler C, Piroth T (2014) Organization of the human fetal subpallium. Front Neuroanat 7:54.

Pelkey KA, Chittajallu R, Craig MT, Tricoire L, Wester JC, McBain CJ (2017) Hippocampal GABAergic inhibitory interneurons. Physiol Rev 97:16191747.

Pleasure SJ, Anderson S, Hevner R, Bagri A, Marin O, Lowenstein DH, Rubenstein JL (2000) Cell migration from the ganglionic eminences is required for the development of hippocampal GABAergic interneurons. Neuron 28:727-740.

Pombal MA, Alvarez-Otero R, Pérez-Fernández J, Solveira C, Megías M (2011) Development and organization of the lamprey telencephalon with special reference to the GABAergic system. Front Neuroanat 5:20.

Puelles L, Kuwana E, Puelles E, Bulfone A, Shimamura K, Keleher J, Smiga S, Rubenstein JL (2000) Pallial and subpallial derivatives in the embryonic chick and mouse telencephalon, traced by the expression of the genes Dlx-2, Emx-1, Nkx-2.1, Pax-6, and Tbr-1. J Comp Neurol 424:409-438.
Sandberg M, Flandin P, Silberberg S, Su-Feher L, Price JD, Hu JS, Kim C, Visel A, Nord AS, Rubenstein JL (2016) Transcriptional networks controlled by NKX2-1 in the development of forebrain GABAergic neurons. Neuron 91:1260-1275.

Seiradake E, del Toro D, Nagel D, Cop F, Hartl R, Ruff T, Seyit-Bremer G, Harlos K, Border EC, Acker-Palmer A, Jones EY, Klein R (2014) FLRT structure: balancing repulsion and cell adhesion in cortical and vascular development. Neuron 84:370-385.

Sjöstedt E, Zhong W, Fagerberg L, Karlsson M, Mitsios N, Adori C, Oksvold P, Edfors F, Limiszewska A, Hikmet F, Huang J, Du Y, Lin L, Dong Z, Yang L, Liu X, Jiang H, Xu X, Wang J, Yang H, et al. (2020) An atlas of the protein-coding genes in the human, pig, and mouse brain. Science 367:eaay5947.

Tanaka DH, Oiwa R, Sasaki E, Nakajima K (2011) Changes in cortical interneuron migration contribute to the evolution of the neocortex. Proc Natl Acad Sci USA 108:8015-8020.

Tong LM, Djukic B, Arnold C, Gillespie AK, Yoon SY, Wang MM, Zhang O, Knoferle J, Rubenstein JL, Alvarez-Buylla A, Huang Y (2014) Inhibitory interneuron progenitor transplantation restores normal learning and memory in ApoE4 knock-in mice without or with a-beta accumulation. J Neurosci 34:9506-9515

Tricoire L, Pelkey DA, Daw MI, Sousa VH, Miyoshi G, Jeffries B, Cauli B, Fishell G, McBain CJ (2010) Common origins of hippocampay Ivy and nitric oxide synthase expressing neurogliaform cells. J Neurosci 30:21652176.

Vogt D, Hunt RF, Mandal S, Sandberg M, Silberberg SN, Nagasawa T, Yang Z, Baraban SC, Rubenstein JL (2014) Lhx6 directly regulates Arx and CXCR7 to determine cortical interneuron fate and laminar position. Neuron 82:350-364.

Whitworth KM, Li R, Spate LD, Wax DM, Rieke A, Whyte JJ, Manandhar G, Sutovsky M, Green JA, Sutovsky P, Prather RS (2009) Method of oocyte activation affects cloning efficiency in pigs. Mol Reprod Dev 76:490-500.

Wichterle H, Garcia-Verdugo JM, Alvarez-Buylla A (1997) Direct evidence for homotypic, glia-independent neuronal migration. Neuron 18:779791.

Wichterle H, Garcia-Verdugo JM, Herrera DG, Alvarez-Buylla A (1999) Young neurons from medial ganglionic eminence disperse in adult and embryonic brain. Nat Neurosci 2:461-466.

Wichterle H, Turnbull DH, Nery S, Fishell G, Alvarez-Buylla A (2001) In utero fate mapping reveals distinct migratory pathways and fates of neurons born in the mammalian basal forebrain. Development 128:37593771.

Wichterle H, Alvarez-Dolado M, Erskine L, Alvarez-Buylla A (2003) Permissive corridor and diffusible gradients direct medial ganglionic eminence cell migration to the neocortex. Proc Natl Acad Sci USA 100:727732

Wonders CP, Anderson SA (2006) The origin and specification of cortical interneurons. Nat Rev Neurosci 7:687-696.

Zhu B, Eom J, Hunt RF (2019) Transplanted interneurons improve memory precision after traumatic brain injury. Nat Commun 10:5156.

Zimmer G, Rudolph J, Landmann J, Gerstmann K, Steinecke A, Gampe C, Bolz J (2011) Bidirectional ephrinB3/EphA4 signaling mediates the segregation of medial ganglionic eminence- and preoptic area-derived interneurons in the deep and superficial migratory stream. J Neurosci 31:18364-18380. 